4[ 1]. o'connor:4[ 1]. o'connor.qxd 7/23/2009 11:2ß PM Page 55

\title{
THE VALUATION EFFECTS OF CROSS-LISTING ABROAD FOR IRISH FIRMS*
}

\author{
Thomas G. O'Connor \\ Department of Economics, Finance and Accounting, \\ National University of Ireland, Maynooth
}

\begin{abstract}
The number of Irish firms cross-listed on international exchanges remains low, relative to other countries. However, as a proportion of those firms eligible to list, Irish firms are, relative to others, more likely to list abroad. Surprisingly, Doidge, Karolyi and Stulz (2004) show that in 1997 US exchange-traded Irish firms are worth less than domestic Irish firms, a result at odds with what we might have expected and with the predictions of the legal bonding hypothesis. In this paper, I show that listing abroad, in both London (AIM listing only) and the US (both Level 1 and Level 2), does enhance the value of Irish firms. I find that cross-listing leads to an average 'within-firm' change in the value of Level 2 firms in the region of 19.65 per cent (using market-to-book of assets). As expected, the change in value experienced by Level 1 firms is smaller (14.93 per cent). Like Doidge, Karolyi and Stulz (2009), I do not find that an ordinary listing in London enhances value. Surprisingly, I find that Irish firms that trade on the Alternative Investment Market (AIM) in London experience the largest valuation gains from listing abroad of all cross-listed Irish firms (27.35 per cent using market-to-book of assets). This is surprising since these firms are subjected to the least onerous governance and regulatory requirements of all cross-listed Irish firms. Ultimately, due to data restrictions, I am unable to delve further in to why the less regulated AIM firms enjoy a larger cross-listing premium relative to Level 2 firms. However, I offer some possible explanations consistent with some findings in the international cross-listing literature.
\end{abstract}

\section{INTRODUCTION}

During the 1990s, the United States became the most attractive location for an international listing of a firm's equity. ${ }^{1}$ While the trends were impressive,

* This paper is based on a revised version of Chapter 4 of my Ph.D. thesis at National University of Ireland, Maynooth. 
O'Connor

Doidge et al. (2004) quote that of those non-US firms eligible to list in the US, only one in ten actually do so. (Claessens and Schmukler (2007) characterise those firms that list abroad, Barzuza (2005) and Barzuza, Smith and Valladares (2006) outline theoretical arguments (with empirical support) as to why others do not.) In contrast, of the number of Irish firms that are eligible to list in the US, a sizable majority does so. Thus it appears that Irish firms view an international listing in the US as potentially valuable for the firm. (In their survey of European corporate managers, Bancel and Mittoo (2001) report that 60 per cent view a foreign listing as potentially beneficial.) Surprisingly, in their study on the valuation effects of listing in the US, Doidge et al. (2004, Table 1, p. 219) document that cross-listed Irish firms (Level 2/3 issues to be specific) are worth in the region of 5 per cent less than their counterpart domestic firms ${ }^{2}$ in 1997, a result at odds with the predictions of the legal bonding hypothesis, ${ }^{3}$ and ultimately with the findings of Doidge et al. (2004). They find that Level 2 and 3 firms enjoy a cross-listing premium of 37 per cent relative to non-cross-listed firms. ${ }^{4}$ In this paper I examine this issue further.

I begin by forming a panel of Irish firms that cross-list, either on the London Stock Exchange or on US exchanges, over the period from 1986 to 2007. A priori, I would expect that the greatest gains to listing abroad should accrue to Level 2 and 3 traded Irish firms. This line of reasoning is based on extending the theoretical model outlined by Doidge et al. (2004). Since the 'cross-listing premium' (i.e. the valuation difference between cross-listed and non-cross-listed firms) is increasing in the 'host' level of investor protection, the greatest gains to listing abroad should accrue to firms that list on an exchange where the governance and regulatory requirements are most stringent (relative to the governance and regulatory requirements faced by other firms from the same country that list abroad on other exchanges). Since the Irish Stock Exchange adopts the UKLA's (United Kingdom Listing Authority) Listing Rules (with some exceptions and modifications), which are the rules that apply to firms listing on the London Stock Exchange (with many exemptions for non-UK firms), this suggests that the greatest gains to listing abroad should accrue to Irish firms that list on organised US exchanges as Level 2 and/or 3 American Depositary Receipts (ADRs).

Using a series of pooled and firm-fixed-effects regressions and proxying for firm value using Tobin's $q$ (see below) and market-to-book of assets, my results suggest that Irish cross-listed firms are worth considerably more than noncross-listed firms (what is commonly referred to as a valuation premium), and cross-listing tends to contribute to this valuation premium (what Doidge et al. (2004) call a cross-listing premium). Irish cross-listed firms tend to enjoy a 'valuation premium' over non-cross-listed firms, which range from 5.32 to 69.32 per cent (and is greatest for AIM-traded firms). The results from firm-fixed-effects regressions suggest that cross-listing abroad is associated with average 'withinfirm' changes in value, which range from 1.90 per cent for Level 1 firms (see below) to a high of 21.61 per cent for AIM-listed firms. Level 2 firms tend to experience average 'within-firm' changes in value in the region of 7.29 per cent (19.65 per cent using market-to-book of assets). My results then suggest that in contrast to the results presented in Doidge et al. (2004), Irish Level 2 firms tend to enjoy a 
cross-listing premium. However, these firms still tend to underperform the average Level 2/3 cross-list (see Doidge et al., 2004, 2009). This result highlights the importance of examining the valuation effects of listing over time and not in any one specific year. Finally, while I find that listing on the main market of the London Stock Exchange does not lead to a 'cross-listing premium' for Irish firms, it does not destroy value, as is the case for the average foreign firm listing in London (see Doidge et al., 2009). ${ }^{6}$

My paper also contributes to the recent literature, which examines the valuation effects of cross-listing both within and across different international equity markets. While the Doidge et al. (2004) model of cross-listing implies that the cross-listing premium is increasing in the host level of investor protection (see endnote 5), the subsequent literature, which examines this hypothesis empirically, is mixed. While Clarkson, Nowland and Ragunathan (2006) and Bianconi and Tan (2007) support the theoretical predictions of the model, more recent studies have questioned these findings. First, Hope, Kang and Zang (2007) find that exchangetraded ADRs from emerging market countries enjoy a cross-listing premium, but in contrast to the predictions of the Doidge et al. (2004) model, the cross-listing premium is greatest for developed market firms. While their paper does not examine the valuation effects of cross-listing across markets, nevertheless their results do suggest that the cross-listing premium may not necessarily increase in investor protection. Second, Doidge et al. (2009) refute the findings of Bianconi and Tan (2007). Unlike them, Doidge et al. (2009) find that while the cross-listing premium is increasing in the host level of investor protection 'within-host country' (i.e. Level 2 and 3 ADRs enjoy the largest cross-listing premium, followed by Level 1 over-the-counter issues; Rule 144a firms (see below) do not enjoy a cross-listing premium), they do not find that this relation holds 'across countries' (i.e. Level 2 and 3 firms enjoy a cross-listing premium, while ordinary and depositary receipt listings in the UK do not). My results are, in part, consistent with the findings of Doidge et al. (2009). Like them, I find that cross-listing on the main market of the London Stock Exchange does not contribute to their 'valuation premia' over non-cross-listed firms. Surprisingly, listing on the less-regulated AIM market is associated with a 'cross-listing premium'. Doidge et al. (2009) are unable to examine the valuation gains to listing on London's AIM market since their sample period ends in 2005. Second, and unlike them, I don't find that the greatest gains to listing abroad accrue to Level 2 lists in the US. While I do document a statistically significant cross-listing premium for these firms, the premium is smaller than the cross-listing premia experienced by AIM-traded firms. The fact that AIM-traded firms enjoy the largest gains from listing abroad suggests that the valuation gains from listing abroad do not necessarily increase in investor protection across different host markets in the manner predicted by the legal bonding hypothesis.

Ultimately, due to data restrictions, I am unable to delve further into why the cross-listing premium for Level 2 firms is smaller than the premium experienced by AIM-listed firms in London. Thus, I can only conjecture that my results may be a result of the following. First, and perhaps consistent with Sarkissian and Schill (2009), the small cross-listing premium experienced by Level 2 firms (relative to 
O'Connor

AIM and the average Level 2 or 3 list) is due in part to the fact that listing in the US is not their first cross-listing. ${ }^{7}$ Sarkissian and Schill (2009) show that the greatest gains from listing abroad for firms with multiple international listings stem from their initial cross-listing. Second, in the case of AIM-traded firms, I hypothesize that the cross-listing premium is a function of several factors: recent evidence suggests that the cross-listing premium is a function of both the costs of initial listing (and the costs of ongoing governance and reporting requirements) and the ability of firms to finance their growth opportunities externally. The Alternative Investment Market (AIM) has proved to be highly successful in providing small (young) firms with a low-cost platform to facilitate their ongoing growth and expansion. Finally, given the ability of Irish listed firms to raise sizable amounts of capital on the AIM, this also suggests that the low level of governance and reporting obligations required of these firms may not be as important, since agency costs in these firms are likely to be low.

The paper proceeds as follows. In the next section, I outline the listing and reporting requirements of firms that cross-list in either the UK or the US. The data is outlined in Section 3. In Section 4, I present the empirical results. Section 5 concludes.

\section{CROSS-LISTING IN THE UNITED STATES AND THE UNITED KINGDOM}

In this section I outline how firms can cross-list in the United States (US) and the United Kingdom (UK). A non-US firm can list in the US, either as an ordinary list, or through a depositary receipt programme. There exist four distinct Amercian depositary receipt types, differing in terms of their trading locale and, more importantly, their ongoing disclosure and regulatory requirements. They are a Level 1 over-the-counter issue, a Level 2 and capital-raising Level 3 exchangetraded depositary receipt, and finally a private placement on Portal under Securities and Exchange Commission (SEC) Rule 144a.

A Level 1 issue is the simplest and cheapest way for non-US firms to access US and non-US capital markets. They trade over-the-counter and also on some exchanges outside of the US. Unlike Level 2 and 3 programmes, Level 1 firms are not obliged to reconcile their accounting procedures to US GAAP (Generally Accepted Accounting Practices) or to file periodic reports with the Securities and Exchange Commission. They require minimal SEC registration and are exempt from the SEC's reporting and accounting obligations under Rule 12g3-2(b). They provide instead an English translation of financial statements prepared according to home country accounting practices.

Level 2 and Level 3 capital raising programmes facilitate non-US firms that wish to list on an organised exchange in the United States. Level 2 issues are sponsored (created voluntarily by the international listing firm) public depositary receipts that do not provide for capital raising in the US. Level 3 provisions facilitate the issuance of new stock in the United States. Unlike Level 1 and Rule 144A firms, a Level 2 or 3 issue obligates the firm to adhere to sizable disclosure, regulatory and legal requirements. Specifically, an exchange-listed issue 
necessitates the firm to conform and adhere to US GAAP, become subject to greater Securities and Exchange Commission scrutiny and become subject to civil liability under Section 18 of the 1934 Securities and Exchange Act. In addition, the Sarbanes-Oxley Act of 2002 requires that CEOs (chief executive officers) and CFOs (chief financial officers) must personally certify that information in each year filed under Form $20-\mathrm{F}$ is accurate and free from material misstatements and omissions, and that the financial statements and other financial information in the report fairly present, in all material respects, the issuer's financial position, results of operations and cash flows. Finally, a Level 2 or 3 issue exposes the firm to the scrutiny of 'Reputational Intermediaries'. These include financial analysts, underwriters, bond rating agencies, auditors and institutional investors.

A Rule 144A depositary receipt programme facilitates access to US and nonUS markets through a private placement of sponsored depositary receipts to Qualified Institutional Buyers (QIBs). Like Level 1 issues, they do not require compliance with US GAAP or SEC registration. Under Regulation S, a company can offer a depositary receipt programme to non-US investors. It is not uncommon for firms to establish a Level 1 ADR in connection with a Rule 144A programme.

Firms can cross-list in London, either on the main market as a depositary receipt (DR) or ordinary issue or on the less regulated Alternative Investment Market (AIM). Like US lists, the different listing options require varying degrees of disclosure and regulation. Specifically, an ordinary listing on the London Stock Exchange requires clearance by the UK Listing Authority (UKLA). However, since the vast majority of firms that cross-list in the UK are not incorporated in the UK, the listing rules that seek to protect minority shareholders do not apply to these firms. Specifically, the combined code on corporate governance, adopted after the Cadbury Report in 1992 and the Hampel Report in 1998, do not apply to firms not incorporated in the UK. However, given the historical ties between the Irish and London Stock Exchanges, the case is different for Irish firms. The Irish Stock Exchange (formerly the Dublin Stock Exchange) was, until 1995, part of the privately run and regulated International Stock Exchange, whose most visible trading location was in London. Prior to 1973, the Dublin (Irish) Stock Exchange was one of the provincial arms of the London Stock Exchange, and from 1973 it, unlike others, retained an independent role, when others such as Manchester and Glasgow were absorbed fully into the London Stock Exchange. Prior to becoming independent of the London Stock Exchange, Irish firms could choose a Dublinonly or a joint listing in both Dublin and London. A number of the older Irish firms, such as Allied Irish Bank, Anglo Irish Bank, Bank of Ireland and CRH (Cement Roadstone Holdings) decided on a joint listing. For example, Anglo Irish Bank listed simultaneously in both Dublin and London on 22 February 1974. (See Table 1 for the exact listing dates.) Since 1995 the Irish Stock Exchange has operated independently of the London Stock Exchange. However, given the origins of the Irish Stock Exchange, it continues to adopt the UKLA Listing Rules, with some exceptions in its 'green pages'. Furthermore, firms listed on the Irish Stock Exchange (ISE) are required to disclose a statement of compliance with the 
O'Connor

Combined Code on Corporate Governance in their annual report. Thus, as a result, a cross-listing on the London Stock Exchange is not associated with any substantive governance improvements for Irish firms.

Typically, non-UK firms trading as an ordinary list on the main market of the London Stock Exchange are, similar to US Level 2 and 3 issues, required to file financial information prepared in accordance with UK or US GAAP or International Accounting Standards (IAS). However, exceptions are made, provided the UKLA deem the existing standards 'protect investors' interests'. For example, the UKLA accept local accounting standards from Japanese firms. The requirements for firms that list on the main market via DRs are even less demanding than those for ordinary listings, in that financial information need not be prepared in accordance with IAS or UK or US GAAP. In this regard, a depositary receipt listing in London is similar to a Level 1 or Rule 144a type depositary receipt listing in the US, in terms of reporting and continuing obligations. All Irish firms trade on the main market as ordinary issues.

Finally, a firm can list on the London Stock Exchange on the Alternative Investment Market (AIM). Typically, the listing requirements on the AIM are minimal. For example, there is no prior trading requirement, no prior shareholder approval for transactions is required and admission documents are not prevetted by the Exchange or by the UKLA. Furthermore, there is no minimum market capitalisation and there is no minimum public float requirement. All that is required for a firm to be admitted to AIM is that it has the support of a nominated advisor ('Nomad') and subsequently the firm has to satisfy only the Exchange's weak disclosure duty.

\section{DATA}

I begin this study by sourcing an initial sample of Irish firms, both active and inactive (formerly dead stocks list on Worldscope), from Worldscope that were publicly listed in any year from 1980 to 2007. Worldscope is a financial database, provided by Thompson Reuters, which includes historical information on over 43,000 global public firms. These firms are drawn from more than 60 developed and emerging market countries. This initial sample is made up of 90 firms. From this initial list, I identify Irish firms that are cross-listed internationally using data from the London Stock Exchange (www.londonstockexchange.com) for United Kingdom lists, and the Bank of New York (www.adrbny.com), Deutsche Bank (www.adr.db.com), JP Morgan (www.adr.com), the New York Stock Exchange (www.nyse.com) and NASDAQ (www.nasdaq.com) for Irish firms cross-listed in the United States. For Irish firms listed on the London Stock Exchange, I classify firms either as having an ordinary listing on the main market or as having a listing on the less regulated Alternative Investment Market (AIM). For firms listed in the US, I identify the initial listing date in the US and the depositary receipt type. In the case of firms with more than one depositary receipt programme (e.g. Allied Irish Bank) or firms that transfer from one depositary receipt level to another, I classify firms in accordance with their first listing (in the US) and ignore 
any subsequent changes. This is a standard approach taken in the literature. To be included in the final sample, firms must meet a minimum data requirement. Firms that are cross-listed at some point in the sample are required to have financial data available at least one year before and one year after the year in which they initially cross-listed. Furthermore, all firms with two or fewer observations are eliminated from the study. Irish firms also traded on Germany's Neuer Market. For example, both Conduit and Trinity Biotech traded on the Neuer Market prior to its abolition. However, both firms are excluded from my analysis since they do not meet the minimum data requirements. Finally, I exclude all non-cross-listed financial firms, but, contrary to other studies, I do not exclude cross-listed financial firms. If I were to do so, I would lose three Irish banking firms listed in the US. Given the small size of my sample, it makes more sense to retain these firms. ${ }^{8}$ After imposing these minimum data requirements, the final sample is made up of 17 firms cross-listed in the United Kingdom, 10 firms cross-listed in the United States and 36 domestic firms. The sample of cross-listed firms is presented in Table 1. Panel A contains Irish firms listed in the United States. These firms are also listed on the London Stock Exchange but, due to data availability, I am only able to examine the valuation effects of listing in the US for these firms. Panel B contains Irish firms listed on the London Stock Exchange but not listed in the US.

For each cross-listed firm, I present the date on which the firm initially listed on the Irish Stock Exchange (data is sourced from Irish Stock Exchange Annuals), the date and type of American Depositary Receipt level, and finally the date and type of UK list. Of the sample of firms listed on the London Stock Exchange, nine are listed as ordinary shares on the main market and five are listed on the AIM. Minmet also trade over-the-counter on the Norwegian Norges Fondsmeglerforbund (NOTC) and on the Berlin Borse, but is included as an AIMtraded firm in my final sample since this was their initial international cross-listing. In keeping with the standard convention in the literature, I identify a firm's initial cross-listing and ignore subsequent listings (unless the firm crossdelists). No Irish firm trades as a depositary receipt on the London Stock Exchange. Irish firms that trade in the US do so either as a Level 1 over-thecounter depositary receipt or as a Level 2 exchange-traded depositary receipt. Level 1 American Depositary Receipts trade as pink sheet issues over-the-counter on NASDAQ. In contrast, Level 2 (and Level 3) American Depositary Receipts trade on organised US exchanges (and NASDAQ). Irish firms also trade in the US as private placements under Rule 144a on Portal, but are excluded from our final sample as they fail to meet the minimum data requirements.

Before I proceed to the next section, a number of points evident from Table 1 are worth noting. First, all of the Irish firms cross-listed in the US do so after having initially listed on the London Stock Exchange. For example, Bank of Ireland and Allied Irish Bank listed in London in 1959 and 1967 respectively. Allied Irish Bank's initial listing in the US was in 1990. However, because Worldscope coverage of Irish firms only begins in 1980, I cannot examine the valuation effects of listing in the UK for these firms. In addition, Sarkissian and Schill (2009) show in their study of firms that have multiple lists on international exchanges that their initial (international) list is associated with the greatest valuation gains. 
TABLE I: SAMPLE DESCRIPTION

In this table, I outline the sample of cross-listed Irish firms. For each firm listed in either London (LSE) or in the United States (ADR), I present the year of (initial) listing on the Irish Stock Exchange (Irish Listing), US crosslisting level (ADR), date of US listing (ADR List), type of LSE listing (LSE) and date of London listing (LSE List). All data are sourced from the Irish Stock Exchange, London Stock Exchange, NASDAQ, New York Stock Exchange, Citibank, JP Morgan and the Bank of New York.

\begin{tabular}{|c|c|c|c|c|c|}
\hline & Irish Listing & ADR & ADR List & LSE & LSE List \\
\hline Panel A & \multicolumn{5}{|c|}{ US-Listed Irish Firms } \\
\hline Allied Irish Bank & $26 / 06 / 1967$ & Level 2 & $01 / 11 / 1990$ & Main Market & $29 / 06 / 1967$ \\
\hline Allied Irish Bank & & I44A/REG S & $24 / 04 / 1998$ & & \\
\hline Anglo Irish Bank & $22 / 02 / 1974$ & Level I & $01 / 10 / 1994$ & Main Market & $22 / 02 / 1974$ \\
\hline Arcon International & August 1980 & Level I & $26 / 08 / 1998$ & Main Market & $03 / 04 / 1995$ \\
\hline Bank of Ireland & |4/0|/|959 & Level 2 & $01 / 11 / 1995$ & Main Market & $14 / 01 / 1959$ \\
\hline $\mathrm{CRH}$ & $05 / 02 / 1973$ & Level 2 & $23 / 07 / 1986$ & Main Market & $05 / 02 / 1973$ \\
\hline Glanbia & $01 / 03 / 1988$ & Level I & 25/09/1998 & Main Market & $08 / 09 / 1988$ \\
\hline Greencore Group & $01 / 01 / 1991$ & Level I & 26/04/1999 & Main Market & $26 / 04 / 1991$ \\
\hline Horizon Technology & $06 / 12 / 1999$ & Level I & 2004 & Main Market & $06 / 12 / 1999$ \\
\hline Kerry Group & $01 / 10 / 1986$ & Level I & 2004 & Main Market & $19 / 04 / 1990$ \\
\hline \multicolumn{6}{|l|}{ Waterford } \\
\hline Wedgewood & January 1967 & Level 2 & $28 / 01 / 1987$ & Main Market & $01 / 12 / 1986$ \\
\hline Panel B & \multicolumn{5}{|c|}{ London-Listed Irish Firms } \\
\hline Abbey & I8/05/I973 & - & - & AIM & $16 / 11 / 2004$ \\
\hline Dragon Oil & $01 / 01 / 1978$ & - & - & Main Market & $31 / 05 / 1996$ \\
\hline Elan & $01 / 01 / 1989$ & Level 3 & $26 / 01 / 1984$ & Main Market & $18 / 11 / 1993$ \\
\hline FBD Holdings & $01 / 01 / 1970$ & - & - & Main Market & $04 / 05 / 1995$ \\
\hline Fyffes & $01 / 02 / 1981$ & - & - & Main Market & $14 / 09 / 1987$ \\
\hline IAWS Group & $01 / 01 / 1988$ & - & - & Main Market & $25 / 06 / 1992$ \\
\hline IFG Group & $28 / 12 / 1996$ & - & - & Main Market & $17 / 07 / 2000$ \\
\hline Kingspan Group & $01 / 05 / 1989$ & - & - & Main Market & $08 / 06 / 1995$ \\
\hline Mclnerney Holdings & $01 / 11 / 1971$ & - & - & Main Market & $06 / 01 / 1997$ \\
\hline Minmet* & $12 / 04 / 1988$ & - & - & AIM & $16 / 12 / 2005$ \\
\hline Norish & $01 / 03 / 1986$ & - & - & AIM & $29 / 0 I / 200 I$ \\
\hline Petroceltic & $29 / 07 / 1994$ & - & - & AIM & $26 / 09 / 2001$ \\
\hline Providence Resources & 09/09/1997 & & & AIM & $24 / 06 / 2005$ \\
\hline United Drug & 1989 & - & - & Main Market & $05 / 03 / 1992$ \\
\hline
\end{tabular}

"Minmet also trades over-the-counter on the Norwegian Norges Fondsmeglerforbund (NOTC) and on the Berlin Borse.

Consequently, if these results hold for Irish firms (which I cannot show), my empirical analysis, presented in the next section, suggests that listing in the US for these firms may not be as value-enhancing relative to firms that list initially in the US.

To measure firm value, I follow Doidge et al. $(2004,2009)$ and Hope et al. (2007) and employ Tobin's q. Mitton and O'Connor (2008) also use Tobin's $q$ to 
proxy for value in their study of the relationship between investability (firms that become open to foreign ownership) and firm value. Tobin's $q$ is defined as the book value of debt plus market capitalisation divided by the book value of assets. Ultimately, like others, my definition of Tobin's $q$ deviates from the original definition by proxying for the market value of debt using its book value counterpart and measuring the replacement cost of assets as the book value of assets. For robustness' sake, I also use market-to-book of assets and Relative q. Like Gozzi, Levine and Schmukler (2008), I calculate Relative $q$ as the value of each international firm divided by the average value of all domestic Irish firms.

I control for firm- and industry-related factors commonly employed in other studies using Tobin's $q$ (see Doidge et al., 2004, 2009; Gozzi et al., 2008; Mitton and $\mathrm{O}^{\prime}$ Connor, 2008). I use the average (geometric) sales growth (inflation-adjusted) over the last two years and global industry $q$ to control for firm and industry growth respectively. Based on primary standard industry classifications, (the yearly) mean global industry $q$ is calculated as the average $q$ of all firms (Irish and international) within that classification. ${ }^{9}$ I use log of sales (inflation-adjusted and in euros), rather than total assets (given the definition of Tobin's $q$ ) to control for firm size. Like King and Segal (2008), I also control for firm leverage and profitability. Leverage is calculated as total debt to assets, and profitability as earnings before interest and taxation to total assets. Tobin's $q$ (and other proxies for firm value), sales growth, firm size, leverage and profitability are Winsorized at the 1 and 99 per cent tails of the distribution to remove the confounding effects of outliers.

\section{EMPIRICAL RESULTS}

This section presents the main results on cross-listing and firm value. First, I begin with univariate comparisons. The results are presented in Tables 2 and 3. I then proceed to panel regression estimates (pooled ordinary least squares and firmfixed effects) of the effect of cross-listing on firm value.

\section{Year-by-Year Valuation Comparisons}

In Table 2, I compare the value of cross-listed to non-cross-listed firms in each year from 1986 to 2007. To compare the value of cross-listed firms to non-crosslisted firms, I do the following. For each set of cross-listed firms, I outline the mean value in each year. For each year, I calculate the mean (Diff) and median (Diff*) difference in value between cross-listed and non-cross-listed firms. Finally, for each year, I test whether the mean (and median) difference in value between the two groups is statistically significant using a t-test (z-test for medians). The final row of Table 2 contains the same calculations for the entire sample period.

The results from Table 2 suggest the following. First, cross-listed firms tend to be worth more than non-cross-listed firms. Specifically, using the mean difference 
O'Connor

TABLE 2: COMPARISON OF CROSS-LISTED TO NON-CROSS-LISTED FIRMS IN CALENDAR TIME

The table outlines the average value of cross-listed firms in calendar time. Value is proxied using Tobin's $q$. Tobin's $q$ is measured as ((book value of debt + market capitalization)/book value of assets), where book value of debt is measured as the book value of assets less the book value of equity. Level I and Level 2 denotes Irish firms listing in the US, either as a Level I over-the-counter issue or as an exchange-traded Level 2 issue. London (Ord.) and London (AIM) denote Irish firms listing on the London Stock Exchange either as an ordinary list on the main market or on the Alternative Investment Market (AIM). All data is sourced from the London Stock Exchange, NASDAQ, New York Stock Exchange, Citibank, JP Morgan and the Bank of New York. In the remaining columns, I outline the mean (Diff) and median (Diff*) difference between cross-listed and non-crosslisted firms in each calendar year in which firm-level data is available. The row labelled 'ALL' contains mean and median data for the entire sample period. Asterisks denote significance of t-tests and $\mathrm{z}$ tests of the equality of means and medians, where ${ }^{* * *},{ }^{* *}$ and ${ }^{*}$ indicate significance at the I per cent, 5 per cent and 10 per cent levels respectively.

\begin{tabular}{|c|c|c|c|c|c|c|c|c|c|c|c|c|}
\hline & \multicolumn{3}{|c|}{ Level I } & \multicolumn{3}{|c|}{ Level 2} & \multicolumn{3}{|c|}{ London (Ord.) } & \multicolumn{3}{|c|}{ London (AIM) } \\
\hline & Mean & Diff & Diff & Mean & Diff & Diff" & Mean & Diff & Diff & Mean & Diff & Diff \\
\hline \multicolumn{13}{|c|}{ Panel A: Calendar Time } \\
\hline 1986 & - & - & - & 1.19 & $(0.12)$ & 0.05 & 2.20 & 0.89 & 1.06 & - & - & - \\
\hline 1987 & - & - & - & 1.75 & 0.56 & 0.65 & 2.29 & 1.10 & 1.20 & - & - & - \\
\hline 1988 & - & - & - & $\mathrm{I} .44$ & 0.29 & 0.30 & 1.56 & 0.41 & 0.63 & - & - & - \\
\hline 1989 & - & - & - & 1.26 & 0.00 & 0.17 & 1.45 & 0.19 & 0.20 & - & - & - \\
\hline 1990 & - & - & - & 1.42 & $(0.04)$ & 0.12 & 1.24 & $(0.22)$ & 0.06 & - & - & - \\
\hline |99| & - & - & - & 2.09 & $0.94^{* *}$ & 0.29 & 1.26 & 0.11 & 0.27 & - & - & - \\
\hline 1992 & - & - & - & 1.87 & $0.82^{* *}$ & 0.20 & 1.21 & 0.16 & $0.21^{*}$ & - & - & - \\
\hline 1993 & - & - & - & 1.43 & 0.07 & 0.09 & 1.66 & 0.30 & 0.01 & - & - & - \\
\hline 1994 & - & - & - & 1.45 & 0.09 & 0.12 & 1.76 & 0.40 & 0.12 & - & - & - \\
\hline 1995 & 1.02 & $(0.34)$ & $(0.21)$ & 1.41 & 0.05 & 0.08 & 1.57 & 0.21 & 0.16 & - & - & - \\
\hline 1996 & 1.02 & $(0.37)$ & $(0.25)$ & $\mathrm{I} .47$ & 0.08 & 0.06 & 1.91 & 0.52 & 0.24 & - & - & - \\
\hline 1997 & 1.05 & $(0.46)$ & $(0.35)$ & 1.50 & $(0.0 I)$ & $(0.01)$ & 2.18 & $0.67^{*}$ & $0.28^{*}$ & - & - & - \\
\hline 1998 & 1.35 & $(0.21)$ & 0.05 & 1.42 & $(0.14)$ & $(0.02)$ & I.67 & 0.11 & 0.14 & - & - & - \\
\hline 1999 & 1.21 & $(0.05)$ & $(0.02)$ & 1.44 & 0.18 & 0.09 & I. .47 & 0.21 & 0.11 & - & - & - \\
\hline 2000 & 1.14 & $(0.30)$ & $(0.04)$ & 1.34 & $(0.10)$ & 0.13 & 1.53 & 0.09 & 0.27 & - & - & - \\
\hline 2001 & 1.15 & 0.11 & 0.12 & 1.28 & 0.24 & $0.23^{*}$ & $\mathrm{I} .44$ & $0.40^{* *}$ & 0.47 & - & - & - \\
\hline 2002 & 1.45 & $0.44^{* *}$ & $0.18^{*}$ & 1.17 & 0.16 & 0.07 & 1.18 & 0.17 & 0.01 & 1.86 & 0.85 & 0.82 \\
\hline 2003 & I.79 & $0.66^{*}$ & 0.35 & 1.12 & $(0.01)$ & 0.06 & 1.46 & $0.33^{* *}$ & $0.43^{*}$ & 4.74 & 3.61 & 3.73 \\
\hline 2004 & $1.5 \mathrm{I}$ & $(0.01)$ & 0.45 & 1.15 & $(0.37)$ & $(0.15)$ & 1.90 & 0.38 & 0.34 & 1.89 & 0.37 & 0.67 \\
\hline 2005 & 1.49 & 0.28 & 0.48 & 1.13 & $(0.08)$ & $(0.04)$ & 2.03 & $0.82^{* * * *}$ & $0.73^{* * \alpha *}$ & 2.23 & 1.02 & 0.09 \\
\hline 2006 & 1.42 & $(0.49)$ & $(0.06)$ & 1.31 & $(0.60)$ & $(0.25)$ & 2.19 & $0.28^{* *}$ & $0.35^{*}$ & 2.42 & 0.51 & $(0.25)$ \\
\hline 2007 & 1.43 & 0.30 & 0.31 & 1.25 & 0.12 & 0.13 & 1.66 & $0.53^{*}$ & $0.5 \mathrm{I}$ & 1.05 & $(0.08)$ & 0.02 \\
\hline$A L L$ & 1.37 & $0.13^{*}$ & $0.13^{* * * *}$ & 1.40 & 0.16 & $0.06^{\text {** }}$ & 1.66 & $0.42^{* * *}$ & $0.35^{* * *}$ & 2.23 & $0.99^{* * * *}$ & $0.18^{* *}$ \\
\hline
\end{tabular}


in value, Level 1 firms are worth more than domestic firms in 5 of the 13 years (7/13 for the median firm), 13 of the 22 years for Level 2 firms $(17 / 22$ for the median Level 2 firm), 21 of the 22 years for firms listed as ordinary shares on the main market of the London Stock Exchange (all 22 years for the median firm) and in all 6 years for the mean AIM firm (5 of the 6 for the median firm). Consistent with Doidge et al. (2004), exchange-traded Irish firms were worth less than their domestic counterparts in 1997. The mean (median) valuation differences are statistically significant in 2 (1) years, 2 (1) years, 6 (5) years, and 0 (0) years for Level 1, Level 2, London (ordinaries) and London (AIM) firms respectively.

Over the entire sample period, cross-listed firms, irrespective of the listing type, tend to be worth more than domestic, non-cross-listed firms. The average (median) Level 1 firm has a valuation premium of 0.13 (0.13) relative to non-crosslisted firms. The valuation premium for the average (and median) Level 2 firm is 0.16 (0.06). Interestingly, firms listed in London (both ordinary and AIM lists) experienced the greatest valuation premia. The average (median) valuation premium for ordinary London lists is 0.42 ( 0.35 for the median firm). For AIM-traded firms, the average valuation premium rises to 0.99 (the valuation premium for the median firm is 0.18). Although the evidence in Table 1 suggests that cross-listing is associated with higher firm values, the results should be interpreted with caution given that these univariate comparisons do not control for other factors that are likely to influence firm value (e.g. size, profitability, sales and industry growth, and leverage). I control for these factors in Section 5.

\section{Even-Time Valuation Comparisons}

Table 3 compares the value of cross-listed to non-cross-listed firms, not in calendar time but in event time. This analysis is designed to examine whether there is a significant change in value once the firms cross-list (possibly resulting in a cross-listing premium), or if valuation premia (which we document in Table 2) exist prior to firms cross-listing. To undertake this analysis, I denote the list year as ' 0 ', and compare cross-listed to non-cross-listed firms for the five years before to five years after listing. For each cross-listed sample of firms, I calculate the mean (or median) abnormal value of cross-listed firms relative to non-cross-listed firms in each event year. Abnormal value is calculated as the value of each crosslisted firm in each year less the mean (or median) value of non-cross-listed firms in the same year. In the remaining column, I calculate the Relative $q$ of cross-listed firms in each event year.

Table 3 suggests that for both Level 1 and Level 2 US lists value tends to increase in the run-up to listing and falls off thereafter. The value of Level 1 and Level 2 firms appear to peak around the time of listing, but falls off thereafter, i.e. the mean (median) Level 1 firm is worth, relative to non-cross-listed firms, the most in the year immediately prior to listing. Level 2 firms tend to document a similar trend, and, interestingly, Level 2 firms (mean and median) tend to be worth less than non-cross-listed firms in almost all event time years. Level 1 firms only tend to be worth more than non-cross-listed firms in the years immediately 
O'Connor

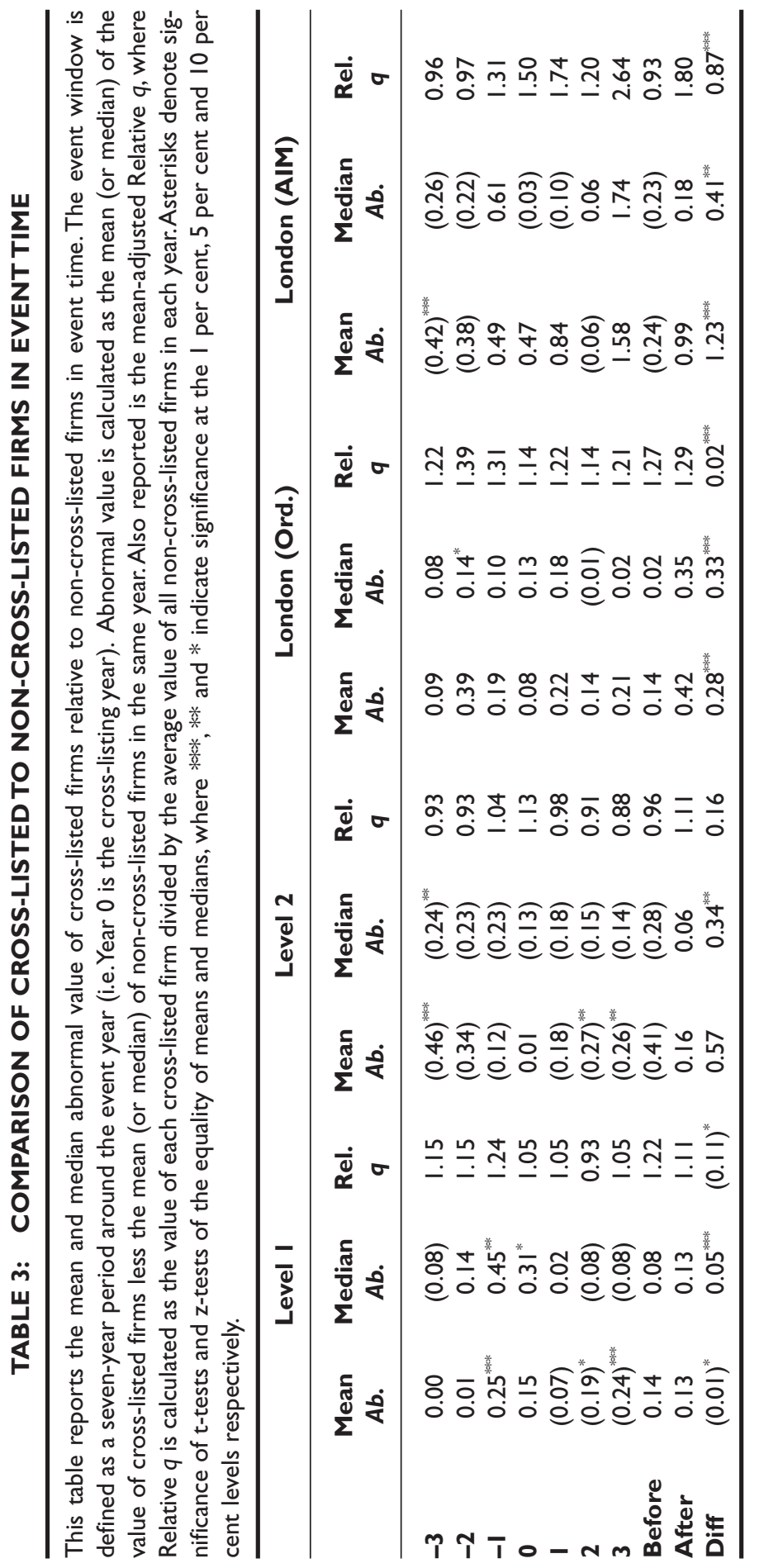


surrounding listing, apparently as a consequence of the increased value that they experience immediately prior to listing. The time-series behaviour of value for Level 1 and Level 2 lists suggests that Irish firms that cross-list in the US appear to 'time' their decision to list internationally. In contrast, firms that cross-list on the London Stock Exchange do not appear to time their listing internationally. ${ }^{10}$ For both sets of firms, there does not appear to be a run-up in value prior to listing in the UK. For the average firm listing in the UK as an ordinary list, value (using Tobin's $q$ ) tends to increase after listing, and remains higher than the value on the list date in each post-listing year. ${ }^{11}$ Finally, the average (and median) AIM list appears to perform similarly to the median ordinary list: value tends to increase once they trade in London, but begins to fall off thereafter.

I supplement Table 3 with a graphical depiction of firm value for cross-listed firms in event time as depicted in Figure 1. I present graphs for both Tobin's $q$ and market-to-book of assets. Figure 1 again suggests that for Level 1 and Level 2 firms value tends to peak around the time of listing and falls off thereafter. ${ }^{12}$ London lists (ordinary (median) and AIM (average and median)) tend to experience an immediate appreciation in value once they list, subsequently followed by a fall-off. The time-series behaviour of value for Irish Level 1 and Level 2 firms is consistent with the time-series patterns of Tobin's $q$ for firms that internationalise as reported by Gozzi et al. (2008), firms that cross-list as reported by Doidge et al. (2009) and King and Segal (2008), and for firms that become investable, as reported by Mitton and $\mathrm{O}^{\prime}$ Connor (2008). ${ }^{13}$ I supplement this analysis by following King and Segal (2008) and also proxy for firm value using price-to-earnings (PE) and enterprise value to EBITDA (earnings before interest, taxation, depreciation and amortization). The time-series behaviour of both valuation metrics around the time of cross-listing is presented graphically for each set of cross-listing firms in Figure 2. In general the trends are similar to those depicted by Tobin's $q$ and the market-to-book of assets.

In the remaining columns of Table 3, I outline the value of cross-listed firms relative to the average non-cross-listed firms in event time. In general, the analysis using Relative $q$ suggests that the change in value experienced by cross-listed firms around the time of listing is experienced by the cross-listing firm alone. For example, in line with the average (and median) absolute value of Level 1 and Level 2 firms, mean-adjusted Relative $q$ experiences an appreciation prior to listing, followed by depreciation thereafter. Finally, and more revealing, is the fact that cross-listed firms tend to be worth more than non-cross-listed firms even prior to becoming cross-listed. Level 1 and London ordinary firms are worth more than non-cross-listed firms in every pre-listing period. Level 2 firms are only worth more than non-cross-listed firms in the years immediately around the time of listing (as a result of the appreciation in value that they experience around the time of listing). AIM firms become more valuable than non-cross-listed firms one year prior to listing, and remain more valuable thereafter. The fact that crosslisted firms tend to be worth more than non-cross-listed firms suggests that cross-listing may not have a causal effect on firm value. In Section 5, I seek to establish the causal effect of listing on firm value using a series of pooled and firm-fixed-effects regressions. 
O'Connor
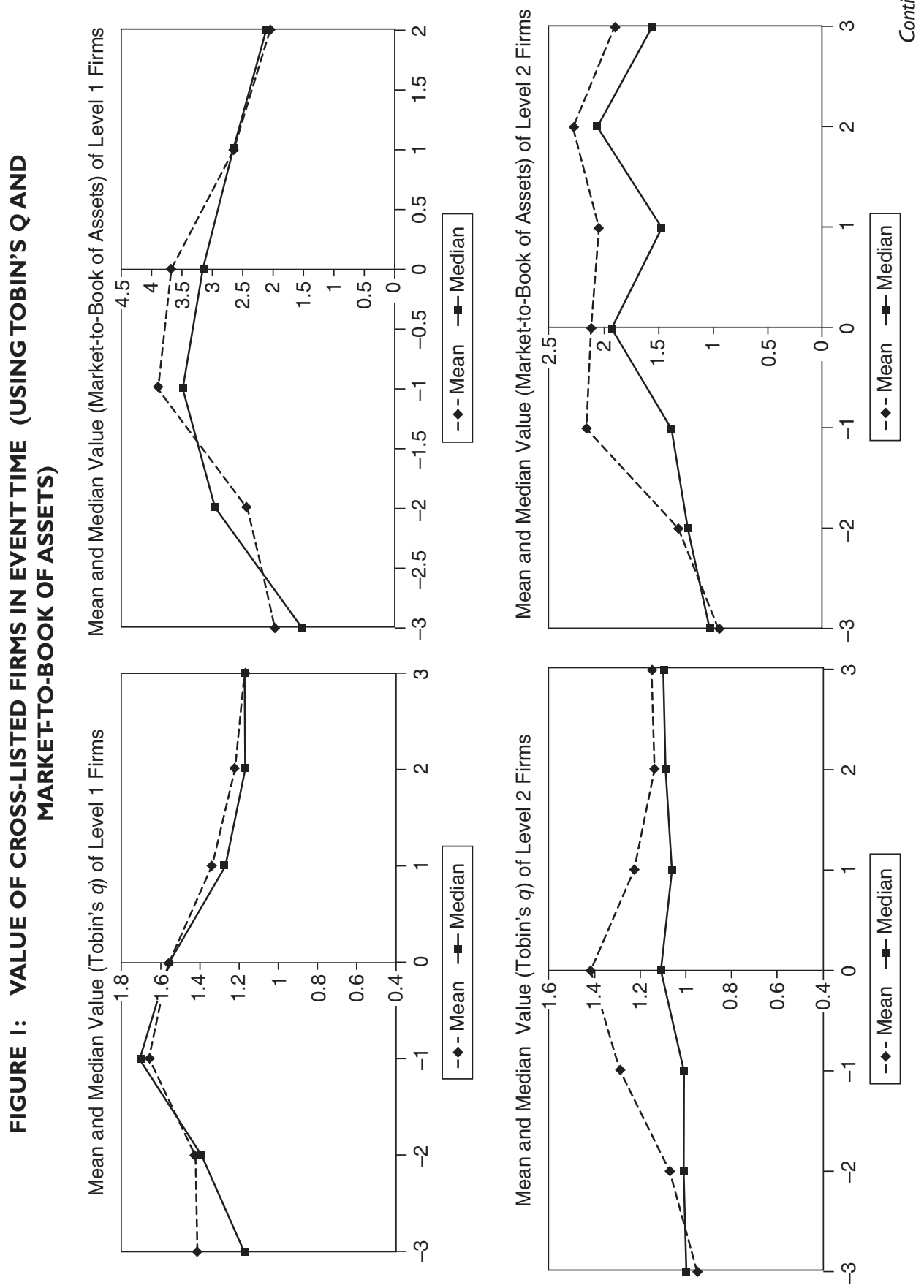
The Valuation Effects of Cross-Listing Abroad for Irish Firms
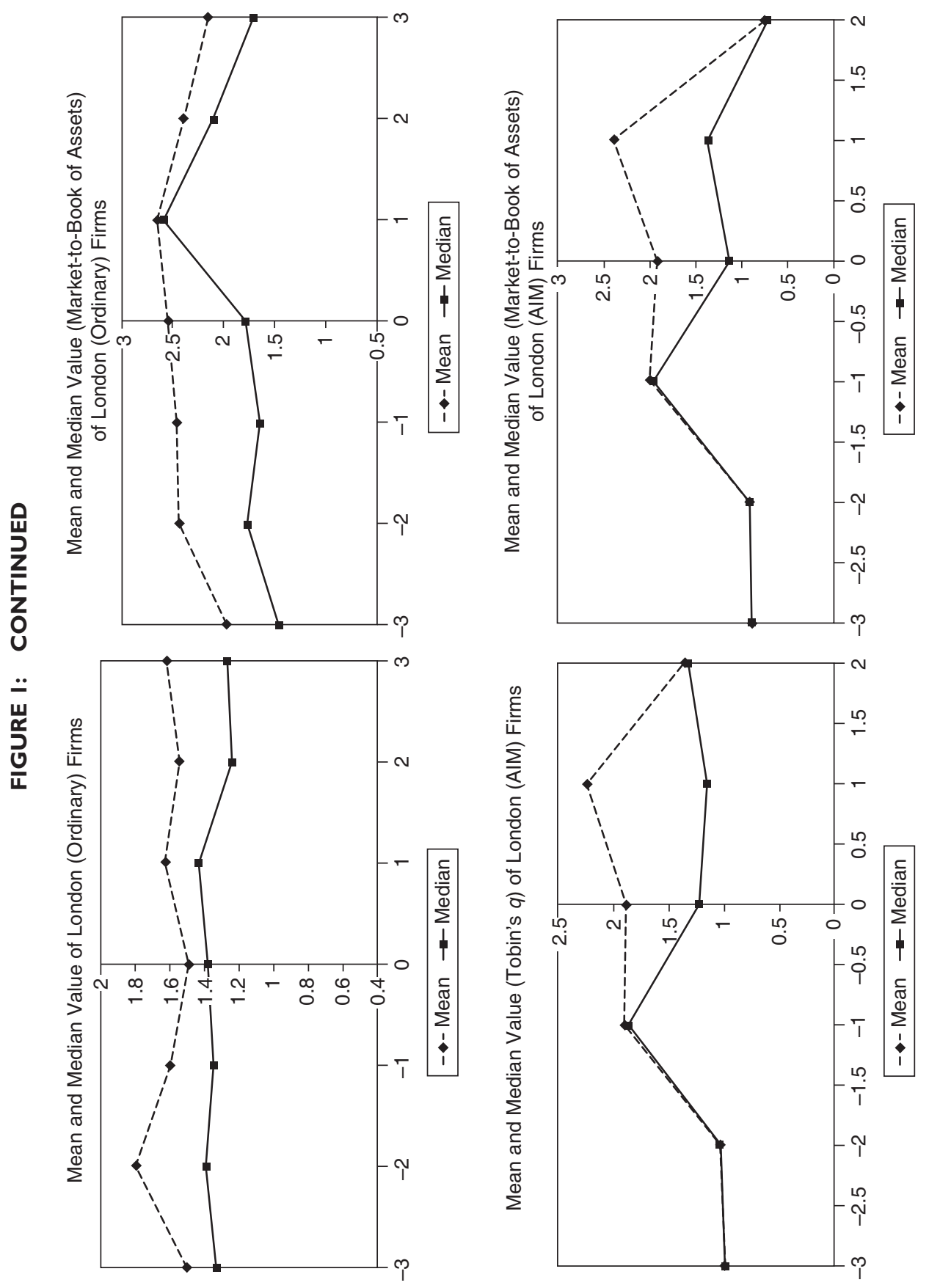
O'Connor
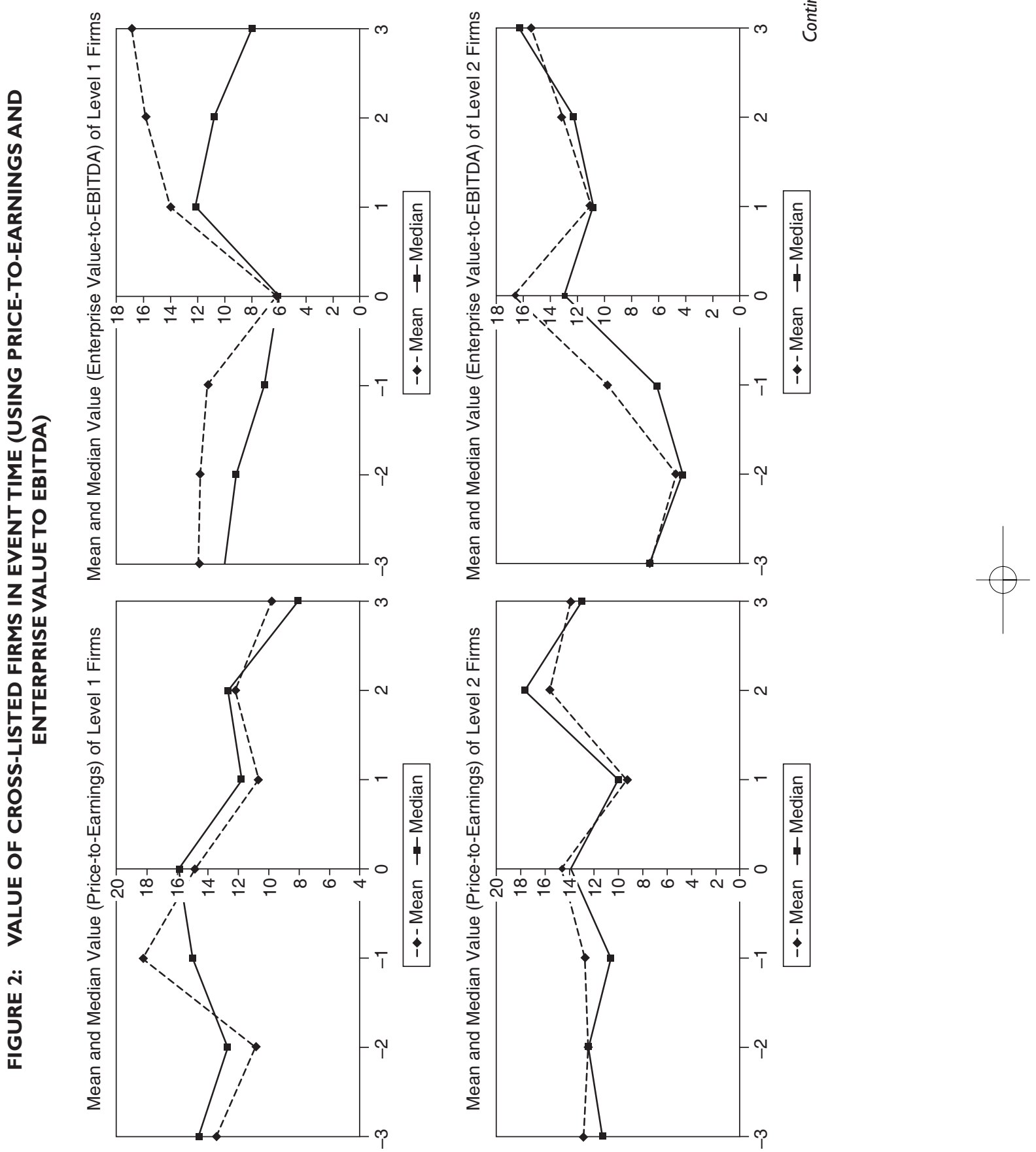
The Valuation Effects of Cross-Listing Abroad for Irish Firms
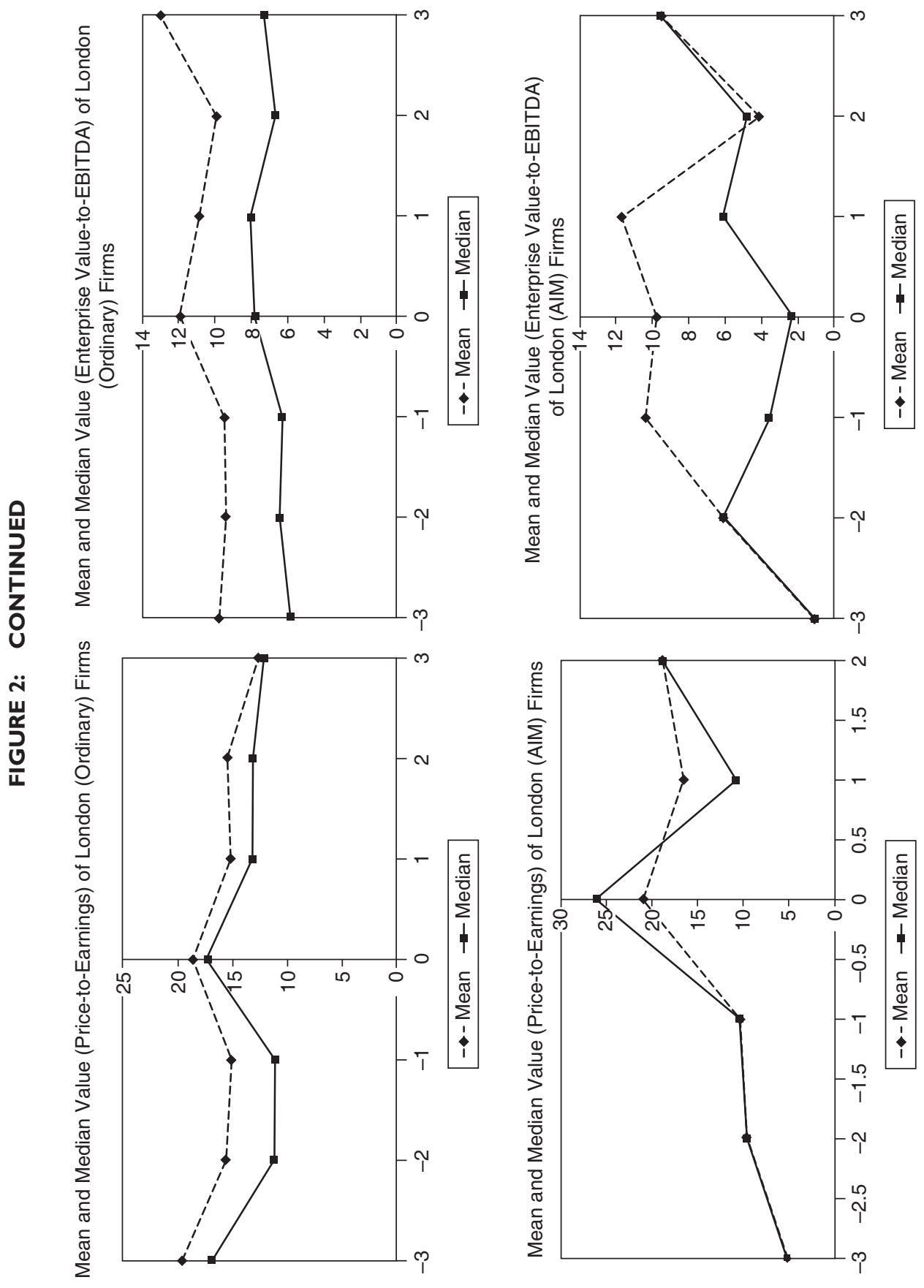
O'Connor

The last three rows of Table 3 summarise the value of cross-listed firms relative to non-cross-listed firms in the pre- and post-listing periods. On a mean- and medianadjusted basis, Level 2 and both sets of London-listed firms tend to worth more than non-cross-listed firms, on both an absolute basis (see Relative $q$ ) and also relative to the pre-listing period. In turn, the mean and median differences tend to be statistically significant (with the exception of the mean Level 2 firm). In contrast, Level 1 firms tend to be worth less, on an absolute (mean firm) and relative basis. However, we should be cautious in interpreting these figures. While the differences are statistically insignificant, the changes in value may well be driven by factors other than crosslisting. In the next section I control for these other factors. Level 1 firms tend to be worth less, although the average and median differences are statistically insignificant.

\section{Regression Estimates}

In this section I examine the relationship between cross-listing and firm value, conditional on firm and industry controls. Specifically, I estimate the following panel (pooled ordinary least squares) regression:

$\mathrm{q}_{\mathrm{it}}=\mathrm{a}+\beta_{1} \mathrm{LI}_{\mathrm{it}}+\beta_{2} \mathrm{~L} 2_{\mathrm{it}}+\beta_{3}$ London(Ord $)_{\mathrm{it}}+\beta_{4}$ London(AIM) $)_{\mathrm{it}}+\beta_{5} \mathrm{X}_{\mathrm{it}}+$ Year $_{\mathrm{t}}+\varepsilon_{\mathrm{it}}$

Where $\mathrm{q}_{\mathrm{it}}$ is Tobin's $q, \mathrm{LI}_{\mathrm{it}}, \mathrm{L} 2_{\mathrm{it}}$, London(Ord) $)_{\mathrm{it}}$, London(AIM) it are standard $0 / 1$ dummy variables that correspond to listing over-the-counter as a Level 1 issue, Level 2 exchange-traded depositary receipt, a direct 'ordinary' list, or an Alternative Investment Market (AIM) listing on the London Stock Exchange. Each dummy

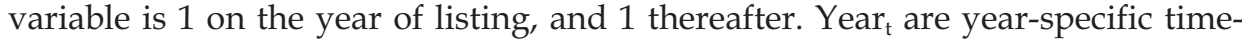
fixed effects and $X_{i t}$ are firm and industry control variables (size, profitability, leverage, and firm and industry growth) that influence firm value. These variables were defined in Section 3.

The coefficient estimates corresponding to Equation (1) are presented in Table 4. Below each coefficient estimate, I present t-statistics (absolute value) in square brackets which are calculated using standard errors clustered at the level of the firm. Clustered standard errors are, by construction, also robust to heteroscedasticity (see Petersen, 2009; Rogers, 1993). Finally, given the small sample size, I bootstrap the standard errors. Bootstrapping is based on building a sampling distribution for a statistic by resampling from the data at hand. Given the panel nature of my data, each replication is a bootstrap sample of firm clusters (instead of individual firm-year observations) (see Petersen (2009) and Cameron, Gelbach and Miller (2007) for a discussion of the relevant issues). The bootstrapped standard errors are generated using 200 replications. Efron and Tibshirani (1986) suggest that for bootstrapped standard errors, 50-200 replications are sufficient.

In column 1 of Table 4, I regress Tobin's $q$ on the cross-listing dummies alone, with time (year) fixed effects included. The coefficient estimates suggest that cross-listing firms tend to be worth more than non-cross-listed firms. Level 1, Level 2, London (Ord.) and London (AIM) have on average a Tobin's $q$ that is $0.086,0.066,0.360$ and 0.867 higher than non-cross-listed firms, respectively. 


\section{TABLE 4: REGRESSION ESTIMATES}

This table reports coefficient estimates from the following pooled ordinary least squares regression:

$$
\mathrm{q}_{\mathrm{it}}=\mathrm{a}+\beta_{1} \text { Level }_{\mathrm{it}}+\beta_{2} \text { Level }_{\mathrm{it}}+\beta_{3} \text { London }(\text { Ord })_{\mathrm{it}}+\beta_{4} \text { London }(\text { AIM })_{\mathrm{it}}+\beta_{5} \mathrm{X}_{\mathrm{it}}+\mathrm{Year}_{\mathrm{t}}+\varepsilon_{\mathrm{it}}
$$

A full set of year-fixed effects are included but not reported. Firm value is measured using Tobin's q. Level I and Level 2 are dummy variables corresponding to a firm's listing in the US. London (Ord.) and London (AIM) are dummy variables corresponding to a firm's listing on the London Stock Exchange either as an ordinary list on the main market or on the Alternative Investment Market (AIM). Firm size is measured as the log of annual sales in real US dollars. Firm growth is measured as the (geometric) average real growth in sales over the prior two years. Global industry $q$ is calculated as the average $q$ of all global firms within each industry classification. Firm leverage is total debt to total assets, and profitability is defined as Earnings Before Interest and Taxation (EBIT) to Total Assets. I report t-statistics (absolute value) in square brackets. The t-statistics are calculated using bootstrapped standard errors (200 replications), whereby each replication is a bootstrap sample of firm clusters (given the panel nature of the data). \# Obs. is the number of observations and $\mathrm{R}^{2}$ is the R-Squared. Statistical significance is denoted by ${ }^{* * * * * *}$, and ${ }^{*}$ for the I, 5 and 10 per cent levels respectively.

\begin{tabular}{|c|c|c|c|c|c|c|}
\hline & (I) & (2) & (3) & (4) & (5) & (6) \\
\hline Level I & $\begin{array}{l}0.086 \\
{[0.86]}\end{array}$ & $\begin{array}{l}0.123 \\
{[1.03]}\end{array}$ & $\begin{array}{l}0.105 \\
{[0.88]}\end{array}$ & $\begin{array}{l}0.156 \\
{[1.31]}\end{array}$ & $\begin{array}{c}0.084 \\
{[0.70]}\end{array}$ & $\begin{array}{l}0.105 \\
{[0.88]}\end{array}$ \\
\hline Level 2 & $\begin{array}{l}0.066 \\
{[0.87]}\end{array}$ & $\begin{array}{l}0.116 \\
{[1.45]}\end{array}$ & $\begin{array}{l}0.109 \\
{[1.38]}\end{array}$ & $\begin{array}{c}0.237^{* * * *} \\
{[2.63]}\end{array}$ & $\begin{array}{l}0.184^{* *} \\
{[2.04]}\end{array}$ & $\begin{array}{l}0.207^{* k} \\
{[2.25]}\end{array}$ \\
\hline London (Ord.) & $\begin{array}{l}0.360^{\text {*w**** }} \\
{[5.80]}\end{array}$ & $\begin{array}{c}0.367^{\text {*atk }} \\
{[5.56]}\end{array}$ & $\begin{array}{c}0.350^{\text {*a*k* }} \\
{[5.30]}\end{array}$ & $\begin{array}{c}0.388^{\text {*a*k }} \\
{[5.88]}\end{array}$ & $\begin{array}{c}0.377^{\text {wak }} \\
{[5.7 I]}\end{array}$ & $\begin{array}{l}0.378^{\text {idiak }} \\
{[5.73]}\end{array}$ \\
\hline London (AIM) & $\begin{array}{l}0.867^{* \text { *ak }} \\
{[5.13]}\end{array}$ & $\begin{array}{c}0.794^{\text {*** }} \\
{[4.54]}\end{array}$ & $\begin{array}{l}0.741^{\text {seder }} \\
{[4.26]}\end{array}$ & $\begin{array}{c}0.577^{\text {**** }} \\
{[3.17]}\end{array}$ & $\begin{array}{c}0.640^{\text {**** }} \\
{[3.56]}\end{array}$ & $\begin{array}{c}0.642^{\text {**** }} \\
{[3.57]}\end{array}$ \\
\hline Global q & & $\begin{array}{c}0.349^{\text {**** }} \\
{[3.00]}\end{array}$ & $\begin{array}{l}0.379^{\text {sodek }} \\
{[3.30]}\end{array}$ & $\begin{array}{c}0.322^{\text {**** }} \\
{[2.78]}\end{array}$ & $\begin{array}{c}0.307^{* * *} \\
{[2.79]}\end{array}$ & $\begin{array}{l}0.292^{\text {*a*k }} \\
{[2.54]}\end{array}$ \\
\hline Firm growth & & & $\begin{array}{l}1.00^{* 0.0 \%} \\
{[3.37]}\end{array}$ & $\begin{array}{l}1.07^{* * * *} \\
{[3.61]}\end{array}$ & $\begin{array}{l}1.09^{\text {**ak }} \\
{[3.76]}\end{array}$ & $\begin{array}{l}1.04^{* * * *} \\
{[3.54]}\end{array}$ \\
\hline Firm size & & & & $\begin{array}{c}-0.049^{\text {***** }} \\
{[2.95]}\end{array}$ & $\begin{array}{c}-0.057^{\text {wate }} \\
{[3.35]}\end{array}$ & $\begin{array}{c}-0.064^{* * * *} \\
{[3.76]}\end{array}$ \\
\hline Firm leverage & & & & & $\begin{array}{c}0.632^{\text {*opk }} \\
{[3.5 \mathrm{I}]}\end{array}$ & $\begin{array}{l}0.665^{\text {***** }} \\
{[3.65]}\end{array}$ \\
\hline Firm profit & & & & & & $\begin{array}{l}0.327 \\
{[1.49]}\end{array}$ \\
\hline Time dummies & Yes & Yes & Yes & Yes & Yes & Yes \\
\hline Firm dummies & No & No & No & No & No & No \\
\hline \# Obs. & 574 & 536 & 536 & 536 & 536 & 536 \\
\hline $\mathbf{R}^{2}$ & 0.177 & 0.190 & 0.208 & 0.221 & 0.240 & 0.243 \\
\hline
\end{tabular}


O'Connor

However, these 'valuation premia' are only statistically significant for both sets of London-listed Irish firms. In the remaining columns of Table 4 I sequentially augment the specification employed in column 1 with firm and industry controls. Column 6 contains the results where all firm and industry controls are included.

I find that while the inclusion of firm and industry controls reduces the coefficient estimate on the AIM dummy, they fail to reduce the statistical significance on both the London (Ord.) and London (AIM) dummy variables. In all six specifications, the coefficient estimates on the London (Ord.) and London (AIM) dummy variables remain large and statistically significant. I find that once I control for firm and industry controls, in line with the analysis presented in Table 2, Level 2 firms tend to be worth more than non-cross-listed firms. In contrast, Level 1 firms tend to be valued on a par with domestic firms. Finally, in all specifications the firm and industry controls are of the correct sign, and remain largely statistically significant. Firm value increases with firm and industry growth. Small, profitable and levered firms tend also to be worth more.

In Table 8, I calculate the magnitude of the 'valuation premia' between crosslisted and non-cross-listed firms using the coefficient estimates from Table 4. Relative to the overall average $q$ of 1.24 for non-cross-listed firms, the coefficient estimates suggest that the 'valuation premia' for London (Ord.) and London (AIM) firms range from 28.23 to 31.29 per cent and from 51.66 to 69.92 per cent respectively. Level 2 firms enjoy an average valuation premium over non-cross-listed firms of 12.35 per cent.

The results from the pooled ordinary least squares regressions suggest that all cross-listed firms, bar Level 1 firms, enjoy substantial valuation premia over noncross-listed firms. Furthermore, the valuation premia tend to be greatest for London-listed firms. However, these results do not establish a causal relationship between cross-listing and firm value. The positive coefficient on the cross-listing dummies may simple indicate that those firms that cross-list are those firms with already higher valuations, i.e. those firms that cross-list self-select, as opposed to being randomly assigned into cross-listing. In fact, the Relative $q$ statistics outlined in Table 2 suggest that this is the case. Furthermore, the coefficient estimates could also be affected by (unobserved) heterogeneity that may not have been adequately captured in the pooled ordinary least squares regressions. To address these concerns, I focus on within-firm changes by re-estimating Equation (1), but now with firm-fixed effects included (to capture the unobserved heterogeneity). Consequently, I estimate the following two-way fixed effects model:

$\mathrm{q}_{\mathrm{it}}=\mathrm{a}+\beta_{\mathrm{L}} \mathrm{LI}_{\mathrm{it}}+\beta_{2} \mathrm{~L}_{\mathrm{it}}+\beta_{3}$ London(Ord $)_{\mathrm{it}}+\beta_{4}$ London(AIM) $)_{\mathrm{it}}+\beta_{5} \mathrm{X}_{\mathrm{it}}+$ Firm $_{\mathrm{i}}+$ Year $_{\mathrm{t}}+\varepsilon_{\mathrm{it}}$

Where Firm $_{\mathrm{i}}$ are firm-fixed effects and all other variables are as explained in Equation (1). In order to estimate the causal effect of listing using firm-fixed effects, I must assume that the unobservables are time-invariant (and, thus, the inclusion of firm-fixed effects adequately controls for unobserved attributes that may influence firm value) and, second, that the unobservables do not have a causal role in precipitating cross-listing (see Li and Prabhala, 2007 for a 
TABLE 5: FIRM-FIXED-EFFECT ESTIMATES OF THE IMPACT OF CROSS-LISTING ON THE VALUE OF IRISH FIRMS

This table reports coefficient estimates from the following panel data regressions with firm-fixed effects:

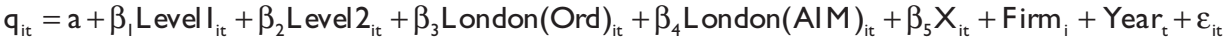

A full set of year-fixed effects are included but not reported. Firm value is measured using Tobin's q. Level I and Level 2 are dummy variables corresponding to a firm's listing in the US. London (Ord.) and London (AIM) are dummy variables corresponding to a firm's listing on the London Stock Exchange either as an ordinary list on the main market or on the Alternative Investment Market (AIM). Firm size is measured as the log of annual sales in real US dollars. Firm growth is measured as the (geometric) average real growth in sales over the prior two years. Global industry $q$ is calculated as the average $q$ of all global firms within each industry classification. Firm leverage is total debt to total assets, and profitability is defined as Earnings Before Interest and Taxation (EBIT) to Total Assets. I report t-statistics (absolute value) in square brackets. The t-statistics are calculated using bootstrapped standard errors (200 replications), whereby each replication is a bootstrap sample of firm clusters (given the panel nature of the data). \# Obs. is the number of observations and $\mathrm{R}^{2}$ is the overall R-Squared. Statistical significance is denoted by ***, *** and * for the I, 5 and I0 per cent levels respectively.

\begin{tabular}{|c|c|c|c|c|c|c|}
\hline & (I) & (2) & (3) & (4) & (5) & (6) \\
\hline Level I & $\begin{array}{l}-0.108 \\
{[0.92]}\end{array}$ & $\begin{array}{l}-0.044 \\
{[0.30]}\end{array}$ & $\begin{array}{l}-0.026 \\
{[0.18]}\end{array}$ & $\begin{array}{l}0.107 \\
{[0.73]}\end{array}$ & $\begin{array}{l}0.124 \\
{[0.86]}\end{array}$ & $\begin{array}{l}0.103 \\
{[0.93]}\end{array}$ \\
\hline Level 2 & $\begin{array}{l}0.140 \\
{[1.17]}\end{array}$ & $\begin{array}{l}0.128 \\
{[1.02]}\end{array}$ & $\begin{array}{l}0.088 \\
{[0.73]}\end{array}$ & $\begin{array}{l}0.057 \\
{[0.46]}\end{array}$ & $\begin{array}{l}0.092 \\
{[0.75]}\end{array}$ & $\begin{array}{l}0.107 \\
{[0.90]}\end{array}$ \\
\hline London (Ord.) & $\begin{array}{l}0.003 \\
{[0.04]}\end{array}$ & $\begin{array}{l}-0.006 \\
{[0.07]}\end{array}$ & $\begin{array}{l}0.013 \\
{[0.15]}\end{array}$ & $\begin{array}{l}0.091 \\
{[1.06]}\end{array}$ & $\begin{array}{l}0.057 \\
{[0.47]}\end{array}$ & $\begin{array}{l}0.029 \\
{[0.34]}\end{array}$ \\
\hline London (AIM) & $\begin{array}{l}0.645^{* * * *} \\
{[3.98]}\end{array}$ & $\begin{array}{c}0.657^{\text {sok }} \\
{[3.93]}\end{array}$ & $\begin{array}{c}0.568^{\text {*owe }} \\
{[3.42]}\end{array}$ & $\begin{array}{l}0.375^{* *} \\
{[2.18]}\end{array}$ & $\begin{array}{l}0.368^{* *} \\
{[2.15]}\end{array}$ & $\begin{array}{l}0.279^{*} \\
{[1.66]}\end{array}$ \\
\hline Global q & & $\begin{array}{l}0.130 \\
{[1.00]}\end{array}$ & $\begin{array}{l}0.165 \\
{[1.27]}\end{array}$ & $\begin{array}{l}0.299^{* * *} \\
{[2.20]}\end{array}$ & $\begin{array}{c}0.342^{* * * *} \\
{[2.53]}\end{array}$ & $\begin{array}{l}0.254^{*} \\
{[1.91]}\end{array}$ \\
\hline Firm growth & & & $\begin{array}{l}0.922^{\text {*atak }} \\
{[3.70]}\end{array}$ & $\begin{array}{l}1.16^{\text {***k* }} \\
{[4.57]}\end{array}$ & $\begin{array}{l}1.07^{* 00 k} \\
{[4.23]}\end{array}$ & $\begin{array}{c}0.894^{\text {*ak }} \\
{[3.58]}\end{array}$ \\
\hline Firm size & & & & $\begin{array}{c}-0.149^{* * * *} \\
{[3.63]}\end{array}$ & $\begin{array}{c}-0.112^{* * * k} \\
{[2.67]}\end{array}$ & $\begin{array}{c}-0.114^{* *+1} \\
{[2.85]}\end{array}$ \\
\hline Firm leverage & & & & & $\begin{array}{c}-0.766^{* * * *} \\
{[3.36]}\end{array}$ & $\begin{array}{c}-0.535^{* *} \\
{[2.35]}\end{array}$ \\
\hline Firm profit & & & & & & $\begin{array}{c}0.930^{* * * *} \\
{[4.72]}\end{array}$ \\
\hline Time dummies & Yes & Yes & Yes & Yes & Yes & Yes \\
\hline Firm dummies & Yes & Yes & Yes & Yes & Yes & Yes \\
\hline \# Obs. & 574 & 536 & 536 & 536 & 536 & 536 \\
\hline $\mathbf{R}^{2}$ & 0.109 & 0.118 & 0.151 & 0.129 & 0.097 & 0.102 \\
\hline
\end{tabular}


O'Connor

discussion). Finally, in order to determine the statistical significance of the firm-fixed effect estimates, I bootstrap the standard errors, as before.

Table 5 presents the coefficient estimates of Equation (2) with t-statistics (absolute), adjusted for heteroscedasticity as in White (1980), presented under the coefficient estimates in square brackets. In column 1, I regress Tobin's $q$ on the cross-listing dummies alone, with firm- and time-fixed effects included. In subsequent columns, controls variables are added in turn. Specification (5) contains the coefficient estimates with all controls included. The primary difference between Tables 4 and 5 is that once we control for unobserved heterogeneity, the coefficient estimates on the Level 2 and London (Ord.) dummies are much smaller, and lose their statistical significance. In contrast, the coefficient estimates on the London (AIM) dummy remains large, and maintains its statistical significance. The coefficient estimate on the Level 1 dummy ranges from negative to positive, but is statistically insignificant in all specifications. These results suggest that cross-listing on international exchanges only causes value for Irish firms that list on the Alternative Investment Market of the London Stock Exchange. In contrast, cross-listing does not contribute to the valuation premia enjoyed by Level 2 and London (Ord.) lists. In summary, only AIM lists enjoy a 'cross-listing premium'.

In the remaining rows of Table 8, I calculate the magnitude of the "cross-listing premium' for all cross-listing Irish firms. Based on the coefficient estimates presented in Table 3, cross-listing abroad leads to an average 'within-firm' change in Tobin's $q$ in the region of $0.03,0.10,0.03$ and 0.48 for Level 1, Level 2, London (Ord.) and AIM traded firms respectively. Relative to an average Tobin's $q$ of 1.37, $1.40,1.66$ and 2.33 respectively for these same firms, this implies that cross-listing abroad causes average 'within-firm' changes in value in the region of 1.90, 7.29, 1.88 and 21.61 per cent for Level 1, Level 2, London (Ord.) and AIM traded firms respectively. Of course, as outlined in Table 5, only AIM-traded firms enjoy a statistically significant cross-listing premium.

In Table 6, I replicate the analysis undertaken in Table 5, but here I use market-to-book of assets in place of Tobin's $q$ as the valuation metric. All control variables, except for global industry $q$, are included, as before. In column 1, I regress market-to-book of assets on the cross-listing dummies alone, with firmand time-fixed effects included. In the remaining columns, control variables are added in turn. Specification (5) contains the coefficient estimates with all controls included. The coefficient estimates for London (Ord.) and London (AIM) firms from Table 6 are in line with those presented in Table 5. Listing in London causes value for London (AIM) firms only. For these firms, trading on the AIM market in London causes an average 'within-firm' change in value of 27.35 per cent. In contrast to the results presented in Table 5, the coefficient estimates on the Level 1 and Level 2 dummies are positive, and statistically significant in some instances. The coefficient estimates imply an average cross-listing premium of 14.93 per cent for Level 1 firms and 19.65 per cent for Level 2 firms.

The coefficient estimates presented in Tables 5 and 6 for Irish firms are in stark contrast to those presented for the entire sample of cross-listed firms reported by Doidge et al. (2009, see Table 9, pp. 60-61). Doidge et al. (2009) 
conclude that the average Level 1 cross-listed firm tends to be worth more than its counterpart non-cross-listed firm and cross-listing abroad is associated with statistically significant 'within-firm' changes in value for these firms. Interestingly, while the coefficient estimates for Irish firms (pooled ordinary least squares and firm-fixed effects) are in line with those presented by Doidge et al. (2009) for their entire sample of firms, using Tobin's $q$, they are statistically insignificant for Irish firms. Second, typically Level 2 and 3 firms enjoy the largest cross-listing premia. The pooled ordinary least squares and firm-fixed-effects coefficient estimates presented by Doidge et al. (2009) are the largest for Level 2 and 3 firms ( 0.25 and 0.06 respectively). In contrast, I find that AIM-traded Irish firms enjoy the largest cross-listing premia. Finally, while Irish firms trading on the main market of the London Stock Exchange do not experience a cross-listing premium, their experience does, nevertheless, compare favourable with the average LSE (ordinary list). Doidge et al. (2009) highlight a 'cross-listing discount' for the average LSE (ordinary) list. Thus, Irish firms listing on the main market of the London Stock Exchange tend to outperform the average LSE list. This may be a reflection of the fact that, unlike many other non-UK firms that list in London, Irish firms adhere

\section{TABLE 6: FIRM-FIXED EFFECTS USING MARKET-TO-BOOK OF ASSETS}

This table reports coefficient estimates from the following panel data regressions with firm-fixed effects:

$\mathrm{mba}_{\mathrm{it}}=\mathrm{a}+\beta_{1}$ Level $_{\mathrm{it}}+\beta_{2}$ Level $_{\mathrm{it}}+\beta_{3}$ London $\left(O r d_{\mathrm{it}}+\beta_{4}\right.$ London $(A I M)_{\mathrm{it}}+\beta_{5} \mathrm{X}_{\mathrm{it}}+\mathrm{Firm}_{\mathrm{i}}+$ Year $_{\mathrm{t}}+\varepsilon_{\mathrm{it}}$

A full set of year-fixed effects and firm and/or industry controls are included but not reported. Firm value is measured using market-to-book of assets. All other variables included are as defined in Table 4. I report t-statistics (absolute value) in square brackets. The t-statistics are calculated using bootstrapped standard errors (200 replications), whereby each replication is a bootstrap sample of firm clusters (given the panel nature of the data). \# Obs. is the number of observations and $R^{2}$ is the overall R-Squared. Statistical significance is denoted by ${ }^{* * * * * * *}$, and ${ }^{*}$ for the I, 5 and 10 per cent levels respectively.

\begin{tabular}{lccccc}
\hline & $(1)$ & $(2)$ & $(3)$ & $(4)$ & $(5)$ \\
\hline Level I & $0.503^{*}$ & $0.514^{* *}$ & 0.423 & 0.420 & 0.409 \\
Level 2 & {$[1.93]$} & {$[1.98]$} & {$[1.59]$} & {$[1.58]$} & {$[1.56]$} \\
& $0.500^{*}$ & $0.428^{*}$ & $0.437^{*}$ & 0.433 & $0.432^{*}$ \\
London (Ord.) & {$[1.92]$} & {$[1.65]$} & {$[1.66]$} & {$[1.63]$} & {$[1.66]$} \\
& 0.115 & 0.128 & 0.057 & 0.059 & 0.010 \\
London (AIM) & {$[0.65]$} & {$[0.73]$} & {$[0.32]$} & {$[0.33]$} & {$[0.05]$} \\
& $0.588^{*}$ & 0.524 & $0.710^{*}$ & $0.71 I^{*}$ & 0.489 \\
Firm controls & {$[1.65]$} & {$[1.46]$} & {$[1.89]$} & {$[1.89]$} & {$[1.32]$} \\
Time dummies & Included & Included & Included & Included & Included \\
Firm dummies & Yes & Yes & Yes & Yes & Yes \\
\# Obs. & 571 & Yes & Yes & Yes & Yes \\
$\mathbf{R}^{2}$ & 0.181 & 571 & 571 & 571 & 571 \\
& & 0.189 & 0.206 & 0.210 & 0.222 \\
\hline
\end{tabular}


O'Connor

to the UKLA Listing Rules with no accommodations. Thus, investors may value these firms more highly than firms that are subject to less stringent listing rules. Doidge et al. (2009) do not present any pooled ordinary least squares or firmfixed-effects coefficient estimates for AIM-traded firms. However, Doidge et al. (2009) do examine the cross-listing premium in calendar time from 1990 to 2005. While they only present data for AIM firms for 2005, the coefficient estimate is 0.27 (compared to 0.16 for Level 2 and 3 firms), and, although statistically insignificant, it is consistent with the valuation premia that I document for AIM-traded Irish firms.

Finally, in Table 7, I present coefficient estimates from pooled ordinary least squares estimates, with unobserved heterogeneity (individual effects) specified as time averages of the regressors, an approach advocated by Mundlak (1978) (see Cameron and Trivedi (2005, p. 719) for a discussion of the issues). In effect, this specification is a variant of the firm-fixed-effects model presented in Equation (2). The motivation behind estimating this Chamberlain (1984) type model is that the firm-fixed estimates presented in Tables 5 and 6 depend crucially upon the assumption that strict exogeneity holds. Strict exogeneity implies that the error term is uncorrelated with the right-hand-side variables in all periods. However, this is unlikely to be the case given feedback effects from firm value to the crosslisting dummy variables. I formally test for this possibility, following Wooldridge (2002), by inserting the one-year forwarded cross-listing variables as independent variables and testing whether their coefficients are jointly equal to zero. While I find that the coefficient estimates are jointly equal to zero, I still proceed to estimate a model robust to feedback effects. This is because the time-series behaviour of Tobin's q, depicted in Figure 1, suggests that, at least for Level 1 and Level 2 lists, feedback effects are likely, i.e. the decision to cross-list is in part based on past values of Tobin's q. ${ }^{14}$ To do so, I estimate a Chamberlain (1984) type model and specify the individual specific effects as Mundlak (1978) corrections: Firm $_{i}=\bar{X}_{i} \zeta+a_{i}$, where $\bar{X}_{i}=\frac{1}{T} \sum_{s=1}^{T} X_{i t}$, and then proceed to estimate the following:

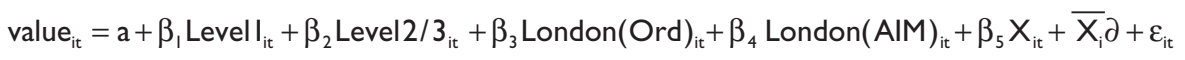

Equation (3) is estimated using pooled ordinary least squares. Pooled estimation circumvents the problems associated with violations of the strict exogeneity assumption because estimation requires, inter alia, the less restrictive assumption of contemporaneous exogeneity.

In summary, my results suggest the following: cross-listed Irish firms (with the exception of Level 1 firms) tend to be worth more than non-cross-listed Irish firms. These 'valuation premia' range from 5.32 to 69.92 per cent, and are largest for AIM-traded Irish firms. Furthermore, in a series of firm-fixed-effects regressions, I find that cross-listing abroad contributes to this premium. On average, listing abroad leads to 'within-firm' changes in value in the region of 1.90, 7.29, 1.88 and 21.61 per cent for Level 1, Level 2, London (Ord.) and AIM traded firms respectively, and 14.93, 19.65, 2.76 and 27.35 per cent using market-to-book of assets. In general, using market-to-book of assets, with the 
TABLE 7: CONTROLLING FOR POSSIBLE FEEDBACK EFFECTS USING MUNDLAK'S (1978) CORRECTIONTERMS

This table reports coefficient estimates from the following pooled ordinary least squares regressions (with Mundlak's (1978) correction terms):

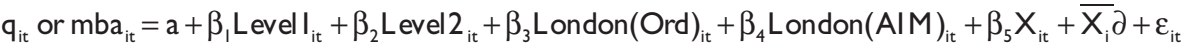

Firm value is measured using Tobin's q, market-to-book of assets (MBA). Level I and Level 2 are dummy variables corresponding to a firm's listing in the US. London (Ord.) and London (AIM) are dummy variables corresponding to a firm's listing on the London Stock Exchange either as an ordinary list on the main market or on the Alternative Investment Market (AIM). Firm size is measured as the log of annual sales in real US dollars. Firm growth is measured as the (geometric) average real growth in sales over the prior two years. Global industry $q$ is calculated as the average $q$ of all global firms within each industry classification. Firm leverage is total debt to total assets, and profitability is defined as Earnings Before Interest and Taxation (EBIT) to Total Assets. I report t-statistics (absolute value) in square brackets. The t-statistics are calculated using bootstrapped standard errors ( 200 replications), whereby each replication is a bootstrap sample of firm clusters (given the panel nature of the data). \# Obs. is the number of observations and $\mathrm{R}^{2}$ is the R-Squared. $\mathrm{Pr}>\mathrm{F}$ (Mundlak) tests the joint significance of the included (unreported) Mundlak (1978) time-averaged correction terms. Statistical significance is denoted by ${ }^{* * * * * * *}$, and ${ }^{*}$ for the I, 5 and 10 per cent levels respectively.

\begin{tabular}{|c|c|c|c|c|}
\hline & \multicolumn{2}{|c|}{ Tobin's q } & \multicolumn{2}{|c|}{ MBA } \\
\hline & (I) & (2) & (3) & (4) \\
\hline Level I & $\begin{array}{l}0.086 \\
{[0.82]}\end{array}$ & $\begin{array}{l}0.069 \\
{[0.49]}\end{array}$ & $\begin{array}{l}1.09^{* * *} \\
{[4.89]}\end{array}$ & $\begin{array}{l}0.640^{* \text { *⿻一从t }} \\
{[2.90]}\end{array}$ \\
\hline Level 2 & $\begin{array}{c}0.066 \\
{[0.85]}\end{array}$ & $\begin{array}{l}0.142 \\
{[1.19]}\end{array}$ & $\begin{array}{l}0.377^{* * *} \\
{[2.27]}\end{array}$ & $\begin{array}{l}0.429^{*} \\
{[1.94]}\end{array}$ \\
\hline London (Ord.) & 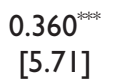 & $\begin{array}{l}0.012 \\
{[0.15]}\end{array}$ & $\begin{array}{c}0.799^{\text {*w*k }} \\
{[5.96]}\end{array}$ & 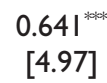 \\
\hline London (AIM) & $\begin{array}{l}0.867^{\text {wesk }} \\
{[5.10]}\end{array}$ & $\begin{array}{l}0.299^{*} \\
{[1.77]}\end{array}$ & $\begin{array}{l}0.125 \\
{[0.34]}\end{array}$ & $\begin{array}{l}0.920^{\text {sident }} \\
{[2.63]}\end{array}$ \\
\hline Global q & & $\begin{array}{l}0.205 \\
{[1.54]}\end{array}$ & - & - \\
\hline Firm growth & & $\begin{array}{c}0.853^{\text {***** }} \\
{[3.38]}\end{array}$ & & $\begin{array}{l}0.680 \\
{[1.17]}\end{array}$ \\
\hline Firm size & & $\begin{array}{c}-0.084^{* *} \\
{[2.10]}\end{array}$ & & $\begin{array}{l}-0.029 \\
{[0.70]}\end{array}$ \\
\hline Firm leverage & & $\begin{array}{c}-0.552^{*} \\
{[1.84]}\end{array}$ & & $\begin{array}{l}2.45^{* * * *} \\
{[5.98]}\end{array}$ \\
\hline Firm profit & & $\begin{array}{l}0.950^{\text {sowe }} \\
{[4.75]}\end{array}$ & & $\begin{array}{l}1.25^{*} \text { *a* } \\
{[2.84]}\end{array}$ \\
\hline Time dummies & No & No & No & No \\
\hline Firm dummies & No & No & No & No \\
\hline Industry dummies & No & No & No & Yes \\
\hline \# Obs. & 574 & 536 & 571 & 571 \\
\hline Pr $>$ F(Mundlak) & 0.000 & 0.000 & 0.000 & 0.000 \\
\hline $\mathbf{R}^{2}$ & 0.137 & 0.221 & 0.167 & 0.365 \\
\hline
\end{tabular}


O'Connor

TABLE 8: ESTIMATES OF VALUATION AND CROSS-LISTING PREMIA BASED ON TABLES 4, 5 AND 6

This table reports estimates of the valuation and cross-listing premia for cross-listed Irish firms. 'Valuation premia' are calculated using coefficient estimates from Table 4. I estimate the 'crosslisting premium' using coefficient estimates from firm-fixed-effects regressions. Table 5 contains the estimates for the mean (and median) firm using Tobin's $q$. Table 6 contains the results using market-to-book of assets. 'Valuation premia' are calculated as follows:

$\left(\frac{\text { value of (average) } n c l \text { firm + coefficient estimate (Table 4) }}{\text { value of (average) } \mathrm{ncl} \text { firm }}\right) * 100$. The 'cross-listing premia' are calculated as $\left(\frac{\text { coefficient estimate (Table } 5 \text { or } 6)}{\text { value of (average or median) cl firm }}\right) * 100$ (from Tables 5 and 6). Figures in bold represent statistically significant premia at conventional levels.

Table 4: Pooled Ordinary Least Squares (Using Tobin's q)

\begin{tabular}{lccccccc}
\hline & Mean & \multicolumn{1}{c}{ (1) } & \multicolumn{1}{c}{ (2) } & \multicolumn{1}{c}{ (3) } & (4) & (5) & (6) \\
\hline Level I & 1.37 & $6.94 \%$ & $9.92 \%$ & $8.47 \%$ & $12.58 \%$ & $6.77 \%$ & $8.47 \%$ \\
Level 2 & 1.40 & $5.32 \%$ & $9.35 \%$ & $8.79 \%$ & $19.11 \%$ & $\mathbf{1 4 . 8 4 \%}$ & $\mathbf{1 6 . 6 9 \%}$ \\
London (Ord.) & 1.66 & $\mathbf{2 9 . 0 3 \%}$ & $\mathbf{2 9 . 6 0 \%}$ & $\mathbf{2 8 . 2 3 \%}$ & $\mathbf{3 1 . 2 9 \%}$ & $\mathbf{3 0 . 4 0 \%}$ & $\mathbf{3 0 . 4 8 \%}$ \\
London (AIM) & 2.23 & $\mathbf{6 9 . 9 2} \%$ & $\mathbf{6 4 . 0 3 \%}$ & $\mathbf{5 9 . 7 6 \%}$ & $\mathbf{4 6 . 5 3 \%}$ & $\mathbf{5 1 . 6 1 \%}$ & $\mathbf{5 1 . 7 7 \%}$
\end{tabular}

Table 5: Firm-Fixed Effects (Using Tobin's q)

\begin{tabular}{lccccccc}
\hline Mean firm & Mean & $\mathbf{( 1 )}$ & $\mathbf{( 2 )}$ & $\mathbf{( 3 )}$ & $\mathbf{( 4 )}$ & $\mathbf{( 5 )}$ & $\mathbf{( 6 )}$ \\
\hline Level I & 1.37 & $(7.88 \%)$ & $(3.21 \%)$ & $(1.90 \%)$ & $7.81 \%$ & $9.05 \%$ & $7.52 \%$ \\
Level 2 & 1.40 & $10.00 \%$ & $9.14 \%$ & $6.29 \%$ & $4.07 \%$ & $6.57 \%$ & $7.64 \%$ \\
London (Ord.) & 1.66 & $0.18 \%$ & $(0.36 \%)$ & $0.78 \%$ & $5.48 \%$ & $3.43 \%$ & $1.75 \%$ \\
London (AIM) & 2.23 & $\mathbf{2 8 . 9 2 \%}$ & $\mathbf{2 9 . 4 6 \%}$ & $\mathbf{2 5 . 4 7 \%}$ & $\mathbf{1 6 . 8 2 \%}$ & $\mathbf{1 6 . 5 0 \%}$ & $\mathbf{1 2 . 5 1 \%}$ \\
\hline Median firm & Median & $\mathbf{( I )}$ & $\mathbf{( 2 )}$ & $\mathbf{( 3 )}$ & $\mathbf{( 4 )}$ & $\mathbf{( 5 )}$ & $\mathbf{( 6 )}$ \\
\hline Level I & 1.25 & $(8.64 \%)$ & $(3.52 \%)$ & $(2.08 \%)$ & $8.56 \%$ & $9.92 \%$ & $8.24 \%$ \\
Level 2 & 1.18 & $11.86 \%$ & $10.85 \%$ & $7.46 \%$ & $4.83 \%$ & $7.80 \%$ & $9.07 \%$ \\
London (Ord.) & 1.47 & $0.20 \%$ & $(0.41 \%)$ & $0.88 \%$ & $6.19 \%$ & $3.88 \%$ & $1.97 \%$ \\
London (AIM) & 1.30 & $\mathbf{4 9 . 6 2 \%}$ & $\mathbf{5 0 . 5 4 \%}$ & $\mathbf{4 3 . 6 9 \%}$ & $\mathbf{2 8 . 8 5 \%}$ & $\mathbf{2 8 . 3 1 \%}$ & $\mathbf{2 1 . 4 6 \%}$
\end{tabular}

Table 6: Firm-Fixed Effects (Using Market-to-Book of Assets)

\begin{tabular}{|c|c|c|c|c|c|c|}
\hline Mean firm & Mean & (I) & (2) & (3) & (4) & (5) \\
\hline Level I & 3.04 & $16.55 \%$ & $16.91 \%$ & $13.91 \%$ & I3.82\% & $13.45 \%$ \\
\hline Level 2 & 2.27 & $22.03 \%$ & | $8.85 \%$ & $19.25 \%$ & $19.07 \%$ & $19.03 \%$ \\
\hline London (Ord.) & 2.67 & $4.31 \%$ & $4.79 \%$ & $2.13 \%$ & $2.21 \%$ & $0.37 \%$ \\
\hline London (AIM) & 2.21 & $26.61 \%$ & $23.71 \%$ & $32.13 \%$ & $32.17 \%$ & $22.13 \%$ \\
\hline Median firm & Median & (I) & (2) & (3) & (4) & (5) \\
\hline Level I & 2.80 & $17.96 \%$ & $18.36 \%$ & $15.11 \%$ & $15.00 \%$ & $14.61 \%$ \\
\hline Level 2 & 2.29 & $21.83 \%$ & | $8.69 \%$ & $19.08 \%$ & $18.91 \%$ & $18.86 \%$ \\
\hline London (Ord.) & 2.51 & $4.58 \%$ & $5.10 \%$ & $2.27 \%$ & $2.35 \%$ & $0.40 \%$ \\
\hline London (AIM) & 1.29 & $45.58 \%$ & $40.62 \%$ & $55.04 \%$ & $55.12 \%$ & $37.91 \%$ \\
\hline
\end{tabular}

80 
exception of ordinary lists in London, all other cross-listed Irish firms enjoy economic and statistically significant cross-listing premia. AIM-traded firms experience the greatest gains from listing abroad. This is surprising since these firms are subject to the least onerous disclosure and regulatory requirements. In contrast, Level 2 firms, which are subjected to the most stringent disclosure and regulatory requirements, enjoy smaller valuation gains from listing abroad. Furthermore, Irish firms that trade as ordinary lists on the London Stock Exchange, and which are required to provide more comprehensive disclosures than AIM-traded firms, do not experience any valuations gains from listing abroad. Finally, Level 1 firms enjoy a cross-listing premium, but, in line with the results presented by others (see Doidge et al., 2004, 2009), this premium tends to be less than that experienced by Level 2 firms. These results suggest that the valuations gains from listing may not necessarily increase in host market investor protection, both within and across host markets as predicted by the legal bonding hypothesis.

Ultimately, due to data considerations, I am unable to delve further into these results and examine why London (AIM) traded firms enjoy the largest crosslisting premia. Thus, at present I can only offer some possible explanations. First, the small cross-listing premia that I document for Level 2 exchange-traded depositary receipts may be caused by the fact that this listing did not constitute the firm's initial listing abroad; all of these firms listed in London prior to listing in the US. The findings of Sarkissian and Schill (2009) suggest that this is a plausible possibility. Second, all of the exchange-traded firms in my sample are non-capital-raising Level 2 ADRs, as opposed to capital-raising Level 3 depositary receipts. Typically, capital-raising Level 3 firms enjoy larger cross-listing premia. Finally, Bris, Cantale and Nishiotis (2007) show that the economic benefits (as opposed to the statistical significance) associated with bonding to a stricter governance regime is small, and smaller than the benefits derived from listing on markets that were previously segmented. However, given that one would expect that Ireland is more integrated with the UK than with the US, I would still have expected that the greatest gains to listing abroad should have accrued to Irish Level 2 lists.

Furthermore, I am unable to explain why Irish firms that trade on the AIM in London enjoy the largest cross-listing premia. For now, I am only able to offer some possible explanations. First, while the governance requirements of AIM firms is minimal (and thus should lead to a small cross-listing premium as predicted by the legal bonding hypothesis and the model outlined in Section 3), the typical AIM firm is small (and young), and agency costs are typically low in small firms. For these firms, the separation of ownership from control (leading to agency costs) is typically minimal, since those who often control these firms are typically founding members who retain sizable ownership stakes. As a result, the minimal governance requirements may well be sufficiently onerous to ensure that investors hold these firms. In fact, AIM-traded firms have been very successful in acquiring capital in London (see Arcot, Black and Owen, 2007; Rousseau, 2007), which only serves to lend further credence to this argument. Furthermore, we know from the theoretical model outlined in Doidge et al. (2004) that the crosslisting premium is increasing with firms' growth opportunities. An AIM listing 
O'Connor

provides a platform for firms to fund these growth opportunities. Second, the costs associated with listing on the AIM market (and subsequent capital raisings) are typically smaller than comparative costs on other exchanges. In fact, many firms have cited this as a reason for choosing the AIM market. This is important, since many firms have in recent times cited the excessive costs of (initial) listing (and subsequent ongoing compliance) as a major reason for delisting from US exchanges. ${ }^{15}$ Hope et al. (2007) theorize that the costs of listing ensure that the cross-listing premia experienced by exchange-traded emerging market firms in the US are less than those experienced by counterpart developed market firms. This line of reasoning then suggests that the cross-listing premia experienced by AIM-listed firms may in part be driven by the (low) level of costs associated with such a listing.

\section{CONCLUDING REMARKS}

Given the relatively small size of the Irish Stock Exchange, it is perhaps not surprising that Irish firms have tended to list their shares abroad, in order to access deep and liquid capital markets. While the absolute number of lists is small, the number of Irish firms eligible to list abroad that actually does so is large. In this paper, I examine whether doing so is value enhancing.

The paper is largely motivated by an empirical irregularity outlined in Doidge et al. (2004). They outline a theoretical model, which predicts that exchange-traded depositary receipts (Levels 2 and 3 ) should be worth more than domestic firms pre-listing, and this 'valuation premium' should increase after listing in the US, resulting in a 'cross-listing premium'. However, in 1997, Irish Level 2 and 3 firms are worth less than non-cross-listed firms. In this paper, I examine this issue further.

Using a panel of Irish firms that trade in the UK or the US over the period from 1986 to 2007, I find in a series of pooled least squares and firm-fixed-effect regressions that Irish cross-listed firms tend to be worth more, and cross-listing contributes to this premium. Specifically, I find that Irish firms are worth more than non-cross-listed firms in the region of 5.32 to 69.92 per cent, and this valuation premium is largest for AIM-traded firms. Furthermore, I find in a series of firm-fixed-effects regressions that cross-listing abroad causes an average 'withinfirm' change in value in the region of 8.17 per cent. Surprisingly, given that AIM-traded firms are subject to the least onerous disclosure requirements, these firms enjoy the largest valuation gains (average of 21.61 per cent) from listing abroad. In contrast, while Level 2 firms are subject to the most stringent and demanding disclosure requirements, they experience an average 'within-firm' change in value in the region of 7.29 per cent (using market-to-book of assets it is a statistically significant 19.65 per cent), which is less than that experienced by AIM-traded firms and the average Level 2 or 3 list in the US. In general, Level 1 firms experience valuation gains from listing abroad, but, consistent with Doidge et al. (2004, 2009), they are less than those experienced by Level 2 and 3 lists. Finally, listing on the main market of the London Stock Exchange is not value 
enhancing. Nevertheless, the experience of Irish firms compares favourably with the average foreign firm that lists in London. Doidge et al. (2009) uncover a 'crosslisting discount' for these firms. These results also suggest that the cross-listing premium does not necessarily increase in host market investor protection. While I find that Level 2 firms enjoy greater valuation gains from listing in the US relative to Level 1 firms, Irish AIM-traded firms do better than ordinary lists on the London Stock Exchange. Furthermore, since AIM-traded firms enjoy greater valuation gains than Level 2 lists in the US, at least for Irish firms, this suggests that the cross-listing premium does not increase with the level of investor protection across international equity markets.

Ultimately, I am unable to delve further into the causes of these results due to data restrictions. Nevertheless, I offer some possible explanations. First, it is likely that the small cross-listing premia experienced by Level 2 lists are likely to be caused by the fact that these firms listed in London prior to listing in the US. Sarkissian and Schill (2009) show that a firm's initial international cross-listing provides the greatest valuation gains. In the case of AIM-traded firms, the crosslisting premia are likely to be caused by a number of factors, namely, first that the governance requirements, albeit minimal, may well be sufficiently onerous for investors to hold these firms, since agency costs are likely to be low in these firms. In fact, the ability of these firms to raise capital on the AIM lends further credence to this argument. Second, the costs of initial and continued listing on the AIM are small. Recent evidence suggests that the cross-listing premium is not only a function of the benefits derived from listing, but also the costs involved.

\section{ACKNOWLEDGEMENTS}

I would like to acknowledge the receipt of financial support from the Maynooth Finance Research Group (MFRG) and the Institute for International Integration Studies (IIIS) at Trinity College Dublin. Helpful and invaluable comments were gratefully received from Tom Flavin, Donal O'Neill, Denis Conniffe and Rory McElligott. The paper has also benefited from comments from two anonymous referees. I would also like to thank Maire O'Hurley of the Irish Stock Exchange for clarifying a number of data issues for me. Any remaining errors are entirely my own.

\section{NOTES}

1 A relatively new literature examines the reasons why particular international exchanges become more attractive to 'international firms' than other competing international exchanges. For a recent treatment see Sarkissian and Schill (2008) and Fernandes and Giannetti (2008). A related literature examines how the listing (location) preferences of firms differ across countries (see Pagano, Roell and Zechner, 2002; Sarkissian and Schill, 2004). 
2 Doidge et al. (2004) do not report any results for Irish firms that trade either over-thecounter as Level 1 'pink sheet' issues or as Rule 144a private placements.

3 Although included in many multi-country studies, the study of Irish cross-listed firms has been largely neglected in academic studies. To the best of my knowledge, Cotter (2004) remains the only study that devotes a sizable proportion of his work to the study of Irish ADRs. Gallagher and Kiely (2005) examine the impact of a dual listing on the volume - volatility relationship for 14 Irish firms trading in Dublin and London. Their sample of firms includes a number of Irish firms that trade in the US as ADRs, but the impact of this 'third-listing' is not addressed in their study. Buckland and Mulligan (1996) show that Irish firms that list in London are, relative to Irish firms that list solely on the Irish Stock Exchange, significantly larger and have greater growth opportunities.

4 Subsequent work has shown that the cross-listing premium is increasing in both.

5 Doidge et al. (2004) show that the cross-listing premium is given by: $q=z+\frac{\mathrm{l}+\mathrm{k}}{\mathrm{k}(\mathrm{I}-\mathrm{k})}\left[\mathrm{v}(\mathrm{p}) \mathrm{C}-\mathrm{v}\left(\mathrm{P}_{\text {Host }}\right)(\mathrm{C}+\mathrm{z})\right]$. Differentiating with respect to the host level of investor protection yields: $\frac{\partial \phi}{\partial \mathrm{P}_{\text {Host }}}=-\frac{\mathrm{I}+\mathrm{k}}{\mathrm{k}(\mathrm{I}-\mathrm{k})} \frac{\partial \mathrm{v}\left(\mathrm{P}_{\text {Host }}\right)}{\partial \mathrm{P}_{\text {Host }}}(\mathrm{C}+\mathrm{z})>0$ as $-\frac{\partial \mathrm{v}\left(\mathrm{P}_{\text {Host }}\right)}{\partial \mathrm{P}_{\text {Host }}}>0$.

Thus, all else being equal, the higher the 'host' level of investor protection, the higher the cross-listing premium.

$6 \quad$ Using market-to-book of assets the average valuation gains range from 2.76 per cent for ordinary lists on the London Stock Exchange to a high of 27.35 per cent for AIMtraded firms. The corresponding figures for Level 1 and Level 2 firms are 14.93 and 19.65 per cent respectively.

7 However, one might argue that given that many of these Irish firms choose a simultaneous ISE/LSE listing (under the terms of the ISE/LSE International Stock Exchange agreement), a cross-listing in the US may well have represented these firms' initial cross-listing.

8 One might argue that the inclusion of banking firms may only serve to bias my results against finding positive valuation effects from cross-listing. However, recent work from Abdallah, Abdallah and Zhu (2009)) found that the market reaction experienced by banking firms upon cross-listing in the US appears to be consistent with the reaction experienced by the average non-financial cross-listed firm (see Miller, 1999). In this regard, banking firms appear to behave no differently than non-financial firms upon cross-listing in the US. I would like to thank an anonymous referee for advising me to expand on this issue.

9 Firms are designated into one of thirteen industries based on the following classifications using 4-digit SIC codes: Agriculture and Food (0100-0999 and 2000-2111); Mining and Construction (1000-1999, excluding 1300-1399); Textiles and Printing/Publishing (2200-2799); Chemicals (2800-2824 and 2840-2899); Pharmaceuticals (2830-2836); Extractive (2900-2999 and 1300-1399); Durable Manufacturers (3000-3999, excluding 3570-3579); Transportation (4000-4899); Utilities (4900-4999); Retail (5000-5999); Services (7000-8999, excluding 7370-7379); Computers (7370-7379, 3570-3579 and 3670-3679); Public Administration (9000+).

10 In her paper, Salva (2003) examines the valuation effects of cross-listing in the UK using standard event study analysis. To make comparisons between my paper and hers, I compute and graph cumulative abnormal returns (CARs) using the abnormal returns that she 
reports in Table 3 (Salva, 2003, p. 474) for ordinary lists. The results suggest that ordinary lists experience a run-up in value in the days prior to listing, and fall off thereafter. In each of the ten days post-listing, the CARs are lower than those on the list date.

11 Using market-to-book of assets, the average ordinary list experiences an immediate increase in value once they cross-list, but value tends to fall below the list year value subsequently.

12 The results, using both price-to-earnings (PE) and enterprise value to EBITDA (see Figure 2), suggest that cross-listing in the UK and the US is associated with a prelisting run-up in value, followed by a subsequent fall-off once the firm lists.

13 Doidge et al. (2009) do not present the time-series behaviour of Tobin's $q$ in event time graphically (or in a table). However, the coefficient estimates from their work (Table 1, Panel B) suggests that, like Gozzi et al. (2008) (and Mitton and O'Connor (2008) for investable firms), cross-listed firms experience a run-up in value prior cross-listing, followed by a fall-off subsequent to listing.

14 Using both price-to-earnings (PE) and enterprise value to EBITDA suggests that this is the case for all cross-listing firms (see Figure 2).

15 For example, Skyepharma, a UK firm, delisted from the NASDAQ in 2007 due to the 'expense and burden associated with maintaining compliance with SEC and Nasdaq rules' (Healthcare Finance, Tax \& Law Weekly, 23 May 2007).

\section{REFERENCES}

Abdallah, A.A.L., Abdallah, W. and Zhu, Y. (2009). The Market Reaction to Banks' Overseas Listings: Evidence from American Depositary Receipts, Journal of Financial Decision Making, Vol. 5, No. 2, pp. 1-20.

Arcot, S., Black, J. and Owen, G. (2007). From Local to Global: The Rise of AIM as a Stock Market for Growing Companies, report prepared by the London School of Economics and Political Science.

Bancel, F. and Mittoo, U. (2001). European Managerial Perceptions on the Net Benefits of Foreign Stock Listings, European Financial Management, Vol. 7, No. 2, pp. 213-236.

Barzuza, M. (2005). Cross-Listing, Asymmetric Information and Private Benefits of Control, working paper, Harvard Law School.

Barzuza, M., Smith, D.C. and Valladares, E. (2006). Signaling a Lemon: The Decision Not to Cross-List and High Private Benefits of Control, working paper 74, University of Virginia, School of Law.

Bianconi, M. and Tan, L. (2007). Cross-Listing Premium: Destination US or UK?, working paper, Northwestern Kellogg School of Management.

Bris, A., Cantale, S. and Nishiotis, G. (2007). A Breakdown of the Valuation Effects of International Cross-Listing, European Financial Management, Vol. 13, No. 3, pp. 498-530.

Buckland, R. and Mulligan, C. (1996). Irish Capital Markets: Segmentation and Provision of Secondary Markets, Irish Accounting Review, Vol. 3, No. 1, pp. 111-130.

Cadbury, Sir A. (1992). Report from the Committee on Financial Aspects of Corporate Governance, London: Gee Publishing.

Cameron, A.C., Gelbach, J.B. and Miller, D.L. (2007). Bootstrap-Based Improvements for Inference with Clustered Errors, Law and Economics Paper No. 07/002, Florida State University, College of Law.

Cameron, A.C. and Trivedi, P.K. (2005). Microeconometrics: Methods and Applications, New York, NY: Cambridge University Press. 
O'Connor

Chamberlain, G. (1984). Panel Data, in Z. Griliches and M.D. Intriligator (eds), Handbook of Econometrics, Vol. II, pp. 1247-1318, Amsterdam; London: North Holland.

Claessens, S. and Schmukler, S.L. (2007). International Financial Integration through Equity Markets: Which Firms from Which Countries Go Global, Journal of International Money and Finance, Vol. 26, No. 5, pp. 788-813.

Clarkson, P., Nowland, J. and Ragunathan, V. (2006). Is the Cross-Listing Premium Really Related to Investor Protection?, working paper, Queensland University of Technology.

Cotter, J. (2004). International Equity Market Integration in a Small Open Economy: Ireland January 1990-December 2000, International Review of Financial Analysis, Vol. 13, No. 5, pp. 669-685.

Doidge, C., Karolyi, G.A. and Stulz, R.M. (2004). Why Are Foreign Firms Listed in the US Worth More?, Journal of Financial Economics, Vol. 71, No. 2, pp. 205-238.

Doidge, C., Karolyi, G.A. and Stulz, R.M. (2009). Has New York Become Less Competitive in Global Markets? Evaluating Foreign Listing Choices Over Time, Journal of Financial Economics, Vol. 91, No. 3, pp. 253-277.

Efron, B. and Tibshirani, R.J. (1986). Bootstrap Measures for Standard Errors, Confidence Intervals, and Other Measures of Statistical Accuracy, Statistical Science, Vol. 1, No. 1, pp. 54-77.

Fernandes, N. and Giannetti, M. (2008). On the Fortunes of Stock Exchanges and Their Reversals: Evidence from Foreign Listing Waves, ECGI finance working paper no. 214.

Gallagher, L. and Kiely, D. (2005). Volume and GARCH Effects for Dual-Listed Equities: Evidence from Irish Equities, Irish Accounting Review, Vol. 12, No. 1, pp. 63-82.

Gozzi, J.C., Levine, R. and Schmukler, S.L. (2008). Internationalization and the Evolution of Corporate Valuation, Journal of Financial Economics, Vol. 88, No. 3, pp. 607-632.

Hampel, Sir R. (1998). Committee on Corporate Governance: Final Report, London: Gee Publishing.

Hope, O., Kang, T. and Zang, Y. (2007). Bonding to the Improved Disclosure Environment in the United States: Firms' Listing Choices and their Capital Market Consequences, Journal of Contemporary Accounting and Economics, Vol. 3, No. 1, pp. 1-33.

King, M.R. and Segal, D. (2009). The Long-Term Effects of Cross-Listing, Investor Recognition, and Ownership Structure on Valuation, Review of Financial Studies, Vol. 22, No. 6, pp. $2393-2421$.

Li, K. and Prabhala, N.R. (2007). Self-Selection Models in Corporate Finance, in B. Espen Eckbo (ed), Handbook of Corporate Finance: Empirical Corporate Finance, Amsterdam; London: North-Holland.

Miller, D.P. (1999). The Market Reaction to International Cross-Listings: Evidence from Depositary Receipts, Journal of Financial Economics, Vol. 51, No. 1, pp. 103-123.

Mitton, T. and O'Connor, T.G. (2008). Investability and Firm Value, working paper N192/05/08, Department of Economics, Finance and Accounting, National University of Ireland, Maynooth.

Mundlak, Y. (1978). On the Pooling of Time Series and Cross Section Data, Econometrica, Vol. 46, No. 1, pp. 69-85.

Pagano, M., Roell, A.A. and Zechner, J. (2002). The Geography of Equity Listing: Why Do European Companies List Abroad?, Journal of Finance, Vol. 57, No. 6, pp. 2651-2694.

Petersen, M.A. (2009). Estimating Standard Errors in Finance Panel Data Sets: Comparing Approaches, Review of Financial Studies, Vol. 22, No. 1, pp. 435-480.

Rogers, W. (1993). Regression Standard Errors in Clustered Samples, Stata Technical Bulletin, Vol. 13, pp. 19-23, reprinted in STATA Technical Bulletin Reprints, Vol. 3, pp. 88-94. 
The Valuation Effects of Cross-Listing Abroad for Irish Firms

Rousseau, S. (2007). London Calling? The Experience of the Alternative Investment Market and the Competitiveness of the Canadian Stock Exchanges, Banking and Finance Law Review, Vol. 23, No. 1, pp. 51-105.

Salva, C. (2003). Foreign Listings, Corporate Governance, and Equity Valuations, Journal of Economics and Business, Vol. 55, Nos. 5-6, pp. 463-485.

Sarkissian, S. and Schill, M.J. (2004). The Overseas Listing Decision: New Evidence on Proximity Preference, Review of Financial Studies, Vol. 17, No. 3, pp. 769-808.

Sarkissian, S. and Schill, M.J. (2008). Cross-Listing Waves and the Search for Value Gains, working paper, University of Virginia, Darden School.

Sarkissian, S. and Schill, M.J. (2009). Are There Permanent Valuation Gains to Overseas Listings? Evidence from Market Sequencing and Selection, Review of Financial Studies, Vol. 22, No. 1, pp. 371-412.

White, H. (1980). A Heteroskedasticity-Consistent Covariance Matrix Estimator and a Direct Test of Heteroscedasticity, Econometrica, Vol. 48, No. 4, pp. 817-838.

Wooldridge, J.M. (2002). Econometric Analysis of Cross Section and Panel Data, Boston, MA: MIT Press. 